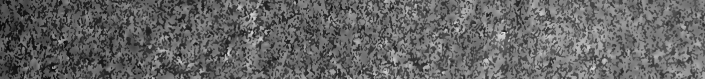 \\ (.)
}

Q.

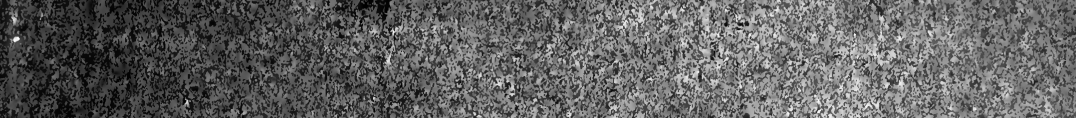

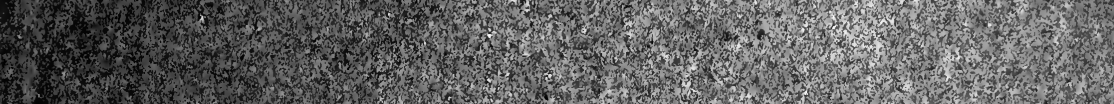

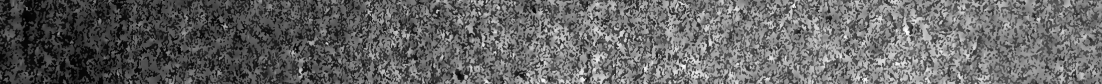
Hin

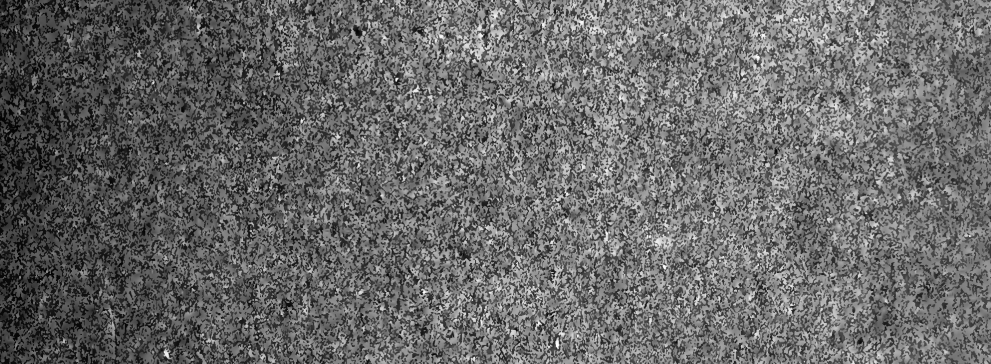
1.7.

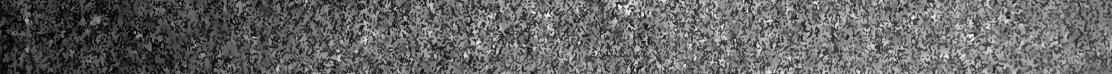
15.

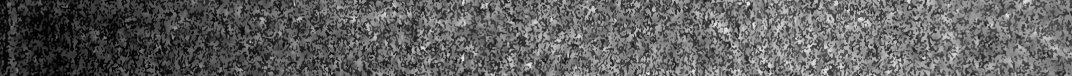
37. 3.7.

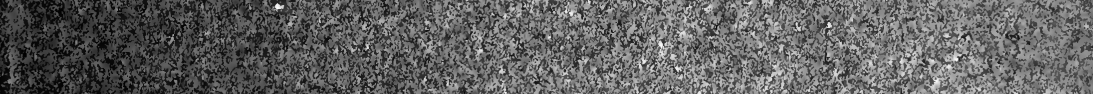
4.7.6.

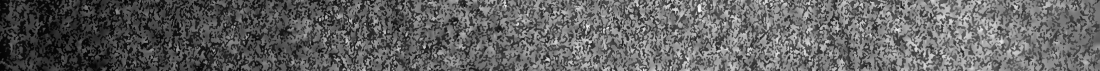
Non S. Q7. 4. 7.

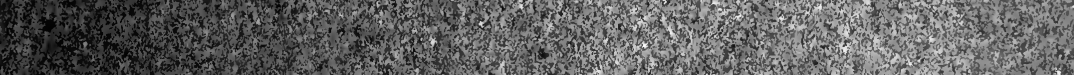

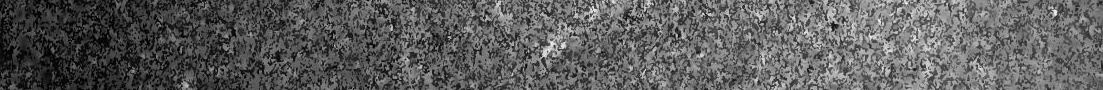

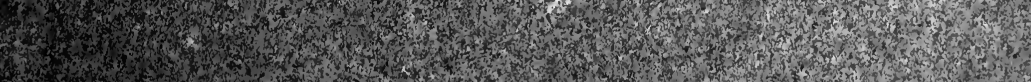

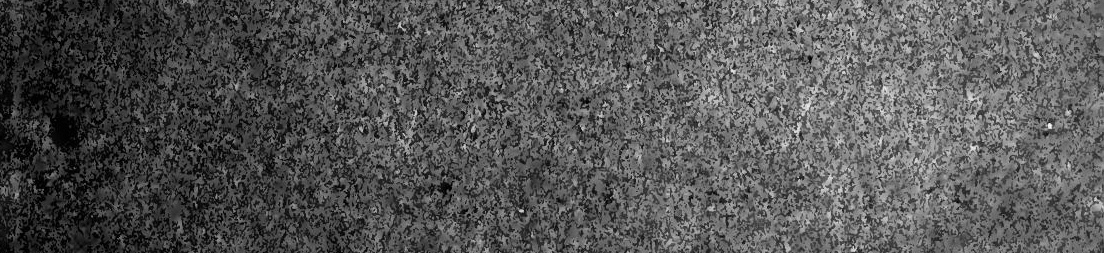


GENEALOGY COLLECTION 


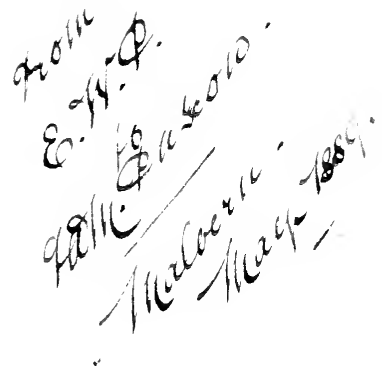




\section{HANLEY AND THE HOUSE OF LECHMERE.}


"The Honours of a Name 'tis juft to guard:

They are a Truft but lent us, which we take, And Mould, in Reverence to the Donor's Fame, With Care tranfmit them down to other Hands." 


\section{H A N LEY}

AND THE

\section{HOUSE OF LECHMERE.}

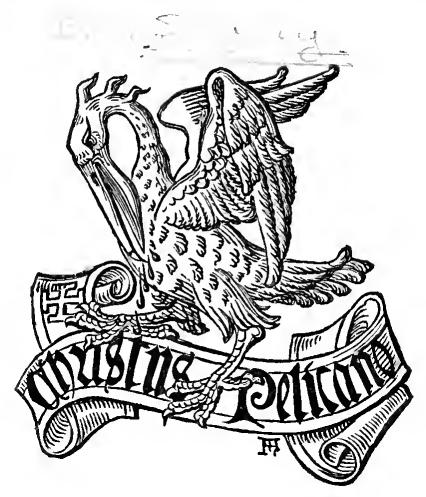

\section{LONDON : \\ PICKERING AND CO.}

I 883. 



\section{9}

To the Memory of Sir Edmund Hungerford Lechmere, second Baronet, of The Rhyd, in the County of Worcester, His Honoured Father in Law,

a bright example of the accomplished and Christian Gentleman,

This sketch of the History of his Family and of the ancient Seat of his Ancestors,

MAINLY REGAINED BY HIS OWN UNSELFISH LABOURS,

IS AFFECTIONATELY INSCRIBED

BY

EVELYN PHILIP SHIRLEY. 



\section{PREFACE.}

THE hand of Death has removed the writer of thefe pages, which were nearly ready for the prefs when he was called to his reft, and it remains for a member of the family whofe ancient feat is defcribed, to place this, the laft work of an accomplifhed antiquary and genealogift, as well as a high-bred Englifh gentleman, before the public.

It was originally intended to be printed privately only, for the immediate ufe of the numerous vifitors to the old feat of the Lechmeres, at Hanley Caftle, in Worcenterfhire; but it was thought that his laft work would poffefs an intereft to the numerous friends and acquaintances who knew the writer, and who would regard it, flight and unimportant as it may appear in comparifon with the former well-known productions of his facile and accurate pen, as fomething beyond a mere ephemeral contribution to local and family hiftory.

Mr. Shirley's alliance with a member of the Lechmere family had made him familiar with all the affociations which clufter round the interefting old manfion which had been for fo many years its anceftral home; but a good deal of the material of the memoir was fupplied by the diary of Sir Nicholas Lechmere, and by the manufcript reminifcences of the late 


\section{Preface.}

Sir Edmund Hungerford Lechmere, the father of the prefent owner of the property.

It is hoped that whilf this little work may fulfil the object for which it was defigned by its author, it may tend to fecure additional intereft in a relic of the part, which has not yielded to modern improvement, and at the fame time to perpetuate the loved memory of one whofe regard for everything connected with the family whofe hiftory he has thus briefly traced, will ever be cherifhed by thofe who furvive him. 



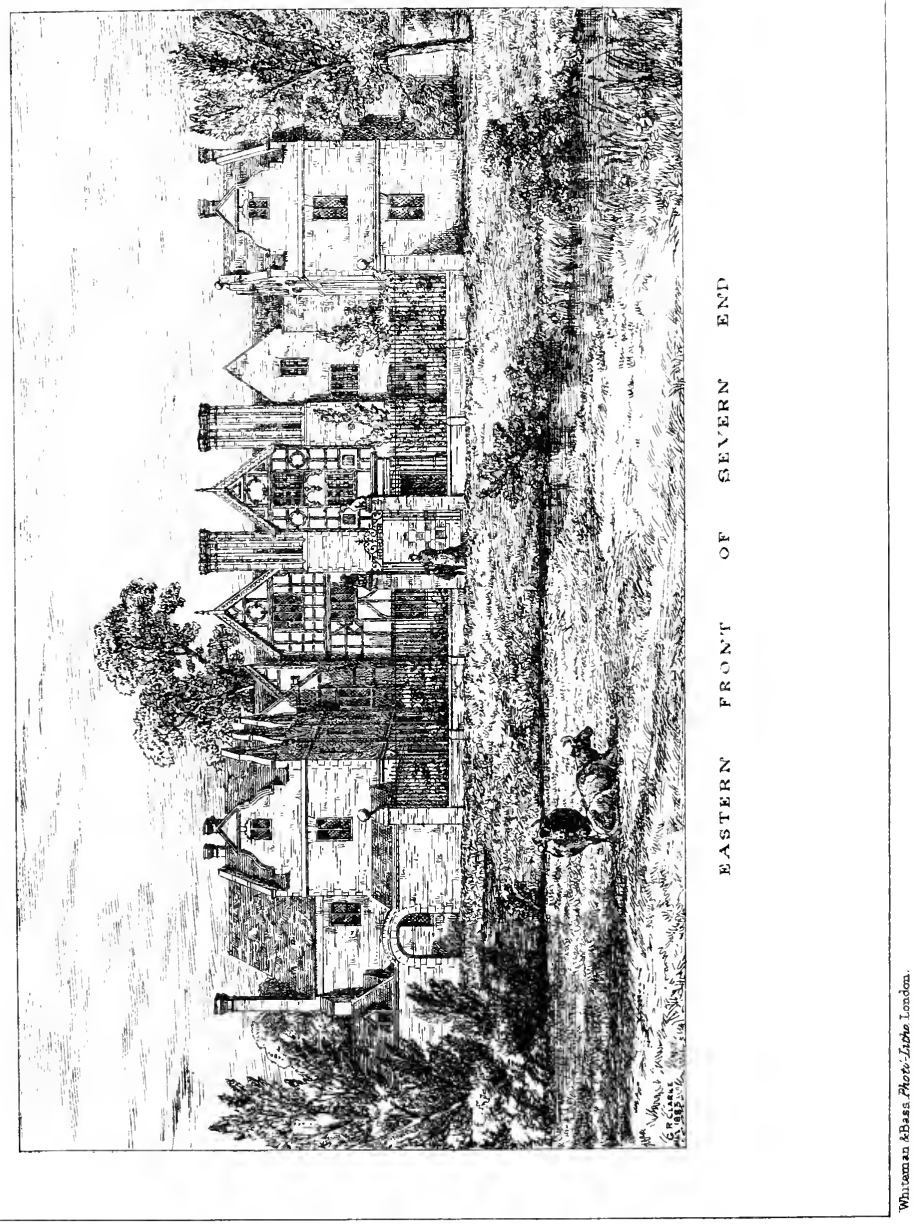




\section{HANLEY AND THE HOUSE OF LECHMERE.}

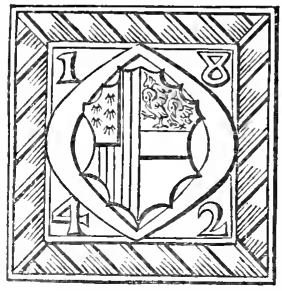

N a rifing bank not far from the River Severn, in the parifh of Hanley-Caftle, in the county of Worcefter, is a venerable houfe, the original feat of the ancient family of LECHMERE, now called SEvERn-END, but formerly LechMERE's Place, or Lechmere's Field, a fite faid to have been in their poffeffion from very early times, and to have been given, fo fays Tradition, by King William the Conqueror to the anceftor of this family. ${ }^{1}$ The parifh of Hanley-Caftle, fo called from the Caftle of the Beauchamps,

1 The tradition, according to the late Sir Edmund Lechmere, was, that the original Grant, defcribed as fmall, with a large pendant feal, was difcovered at Severn End in his grandfather, Mr. Edmund Lechmere's, time, and afterwards came into the poffeffion of his eldest fon, Mr. Lechmere Charlton, who had it at Ludford, as he told Sir Edmund himfelf. Judge Lechmere, however, as appears by his letter to Habington, the Worcefterfhire antiquary, hereafter quoted, p. 47, gives a different account, and refers to " an autbentick record in flaunders," a copy of which he withed to be inferted in Habington's book, but which is not now known to be extant. 


\section{Hanley and the}

Earls of Warwick, and afterwards of the Clares, Earls of Gloucefter, which ftood, fays Leland, " a flite fhotte from Severne," belonged after the Conqueft, as we learn from the Domefday Survey, to Giflebert, the fon of Turold, and was held under him by Roger and Hugh.

The earlieft recorded anceftor of the Lechmeres is "Reginald de Lecbmere de Hanlee," father of Adam de Lechmere de Hanlee; they are mentioned in a deed without date of which there is a note in the College of Arms : ${ }^{1}$ this muft have been about the period of Edward I., after which time deeds were generally dated. A manufcript of Dr. Thomas, quoted by $\mathrm{Nah}$ in his " Hiftory of Worcefterfhire" (vol. i., p. 560), obferves of the Lechmeres: "This family came out of the Low Countries, ferved under William the Conqueror, and obtained lands in Hanley, called from them Lechmere's Place and Lechmere's Field ; Lech is a branch of the Rhine, which parts from it at Wyke, in the province of Utrecht, and running weftward falls into the Maes before you come to Rotterdam."

Some foundation for the fuppofed foreign origin of the name, is derived from the fact that all the earlier anceftors of the Lechmeres ufed the prefix de, which was afterwards dropped, and as, with the exception of Lechmere Heath in Hertfordhire, there is no place of the name in England, we

1 C. 30 , p. 28. "Ex evidentiis $M^{r}$ Edm: Lechmere de Hanley Caftle Com: Wigorn:" 


\section{Houje of Lechmere.}

may, perhaps, conclude that Dr. Thomas's theory is the right one. There can be no reafonable doubt that the progenitor of the venerable Houfe of Lechmere was feated in the parifh of Hanley not long after the Conqueft, and, after all, it may not be impoffible that he was the Roger who held under Giflebert at the time of the Domefday Survey.

The arms which have been, fince the fifteenth century, appropriated to this family, are Gules a fe/s, and in chief two pelicans vulning themfelves or. This coat may be taken as an early inftance of what is called canting Heraldry, Lech in old Breton, meaning love, and mere, of courfe, mother,-a play upon the name, fymbolized by the pelican wounding herfelf, and feeding her young with her blood. A religious appli-

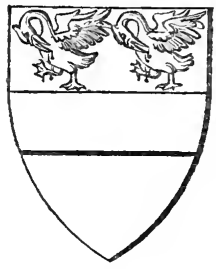
cation was afterwards given to this emblem, and the motto Christus Pelicano appears to have been aflumed by Thomas Lechmere in the reign of Henry VII.

The precife fequence of the earlier defcents of the Lechmeres cannot be accurately afcertained, though feveral pedigrees have been attempted by the Heralds.

In the reign of Edward I., as appears by an original Taxation Roll for a fifteenth in the poffeffion of Sir Edmund Lechmere, I find three of his anceftors taxed at Hanley refpectively at $\mathrm{ij}^{\mathrm{s}} . \mathrm{v}^{\mathrm{s}}$., and $\mathrm{xx}^{\mathrm{d}}$.,-Reginald de Lettemere, Philip de Lettemere, and Richard de Lechmere : the fecond name is erafed. Under Powick alfo in this Roll is preferved the 


\section{Hanley and the}

Lechmere impaling, vert fretty or, Whitmore. name of Henry Letfhimore, taxed at $\mathrm{xx}^{\mathrm{d}}$. Robert, called Wilkyn de Lechmere, was of Hanley in the third of Edward II. Henry, Alice, John, and William occur in the reign of Edward III. The laft was father of Robert, and grandfather of John Lechmere of Lechmere's Place; his fon was Richard

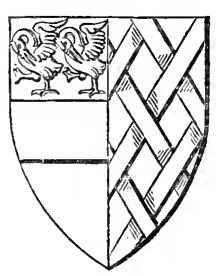
Lechmere of Hanley in the reign of Henry VI., who married Joan, co-heir of John Whitmore, who had lands alfo in Hanley. They appear to have been the parents of John and Thomas Lechmere. The laft was of Hanley in the reign of Henry VII. He married Elianor, daughter of Humphry Frere; they had a fon Richard, living in the twenty-third of Henry VIII., who married Margaret Rock, and was the anceftor of all the future Lechmeres. Of Thomas Lechmere and his defcendants, the celebrated Judge, Sir Nicholas Lechmere, has preferved an interefting account, ftill remaining in MS. ${ }^{1}$ in the poffeffion of his reprefentative, Sir Edmund Lechmere, and which I will now proceed to quote:

" Thomas Lechmere my Father's great grandfather married Elianor daughter of Humfrey Frere of Blankets in the parifh of Claines in the County of Wor $\tilde{\mathrm{r}} \mathrm{Efq}$. and Anne his Wife daughter of Richard Walfh of Sheldifley Walfh in the fame County $\mathrm{Efq}^{\mathrm{r}}{ }^{2}$ They had iffue Richard theyr

1 A large 4 to. in parchment, about 13 inches fquare. Only 18 leaves are filled.

2 Frere of Blankets. See the pedigree of this family in the "Herald and 


\section{House of Lechmere.}

eldeft foñe, and Roger Lechmere ${ }^{1}$ of fanhope in the county of Hereford fecond foñe, frõ $\mathrm{w}^{\text {ch }}$ Roger are defcended the Lechmeres of fanhope. This Elianor was firt married to one Leth, and afterwards to Thomas Lechmere. Shee was borne at Blanketts 22 April 1474, and her Godmothers and Godfather were Elianor Hampton Johanna Habingdon $\mathrm{S}^{r}$ Walter Frances and another woman whofe name I cañot

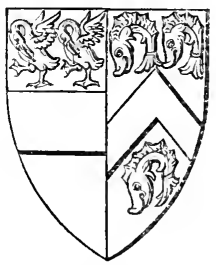
reade for all this I find written by Humfrey frere himfelf in a parchment booke in my poffeffion."

"My great grandfather Richard Lechmere married Margery one of the daughters and coheires of Thomas Rocke of Ripple a Lawyer. Hee feemes to have been a difcreet man and of good efteeme, and comended (even to my daies) for his horpitality, and eminently taken notice of to have been of a gentle behavior. Hee was of great ftature. Hee died March. 23. 1568. and is buried in Hanley Church clofe by the Minifters reading pew.

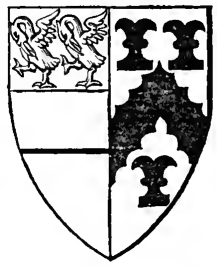

“ My great grandmother Margery Lechmere died 30.

Genealogift," vol. v., p. 429. Where, however, this Elianor does not appear.

1 " Rogerus Lechmere in uxorem duxit Annam Cottrell, viceflimo die Julii ${ }^{5} 548$. Rogerus Lechmere in uxorem duxit Annam Savage decimo die Julii $5557 .,-P . R$. Hanley. 


\section{Hanley and the}

Oct: 1573 . and is buried by my great-grandfather. They were married in Aug: $33^{\circ}$ of Henry ye eighth. I $542 .^{1}$ In theyr time $y^{e}$ eftate of our Family was much increafed, my great grandmother bringing a faire inheritance, but chiefly by the friendhip of Edmund Bonner Bifhop of London, who being borne at Hanley Key (in my Houfe now in the pofsõn of John Hooper ${ }^{2}$ ) of meane parentage, was maintained at School and at Oxford by the liberality of Thomas Lechmere father to my great grandfather; $\mathrm{w}^{\mathrm{ch}}$ hee (afterwards coming to great place) gratefully acknowledged and requited, as by divers letters written by himfelf (yet extant) may appeare."

Thefe letters are no longer preferved, but it may not be out of place here to obferve that it is evident from a letter of

1 The Parish Regifter of Hanley records the baptifms of the following perfons, whom I fuppore to be the iffue of this marriage :-

"Ricũs Lechmere, bapt fuit vii die Januarii, 1545.

" ffrancifces Lechmere, xxi die Martii 1547.

"Maria Lechmere, bapt est xii die Aprilis 1549.

"Elizabethe Lechmere, bapt fuit xiii die Novembris $155^{\circ}$.

" Edmundus Lechmere, bapt fuit xv die Novembris 1550.

“Thomas Lechmere, bapt fuit xvii die Martii 1553.

" Alicia Lechmere, bapt fuit ultimo die Julij, 1555.

"Winifreda Lechmere, bapt fuit feptimo die Septem: 1556."

Alfo the following marriage of Francis Lechmere :-

"Richardus Cholmeley, in uxorem duxit Francisce Lechmere, vicefimo quarto die Aprilis, 157 I."

And the burial of Winifred Lechmere:-

"Winifrida Lechmere, fepulta fuit $\mathrm{I}^{\mathrm{mo}}$ die Septembris 1573 ."

${ }^{2}$ Hanley Key. This houfe is ftill in being, or at leaft one on the fite of it. 


\section{House of Lechmere.}

Bonner's directed " To my loving and dearly beloved Friends, my Coufin Thomas Shirley, The Worfhipful Richard Leechmere \& Roger Leechmere his Brother," printed in Burnet's "Hiftory of the Reformation," ${ }^{1}$ that the requital here mentioned had regard to the Park of Bufhley in Worcefterfhire, a leafe of which was granted by Bifhop Bonner to Richard Lechmere, in the time of Queen Mary, and inquired into by the Privy Council in 159 I. $^{2}$

To refume the Judge's account of his anceftors :-

"Edmund" Lechmere (only foñe of Richard) in July I 575 , and in the $I 7^{\text {th }}$ yeare of Queen Elizabeth, (ye faid Edmund being then about 25 years of age) tooke to wife Anne Dingley (or Dyneley,) one of the Daughters of Henry Dingley of Charlton in the County of Worcenter Efq ${ }^{2}$ by Mary his Wife one of the daughters of $\mathrm{S}^{\mathrm{r}}$ Edward Nevill $\mathrm{k}^{\mathrm{t}}$ brother to the Lord Abergavenny. This Anne Dingley (as I

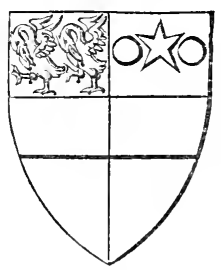
find it regifter'd by her father) was borne the $4^{\text {th }}$ day of feb: I 557. My grandfather Edmund Lechmere was borne I 550 , and dyed año I616, being 66 yeares of age. My father Edm: Lechmere was borne 1577 , and dyed año 1650 , in the $74^{\text {th }}$ yeare of his age. Frố $y^{e}$ birth of my grandfather

1 Ed. 1715 , vol. ii., p. 225.

2 "Calendar of State Papers, Domeftic," I 59I-I 594, p. 29.

3 Edmund, the name (fince hereditary) of Bifhop Bonner, probably his Godfather.

Lechmere, impaling, argent, a $f e f s$ in chief, a mullet fable between two ogrefles. Dyneley. 


\section{Hanley and the}

año $155^{\circ}$, to the death of my father año 1650 , one hundred yeares.

" My grandfather Edmund Lechmere died at Tragod (one $M^{r}$ Seabornes Houfe) in the parifh of Lanruthall in Herefordhire, ${ }^{1}$ whither hee was fled to obfcure himfelf (there being at that time fome profecution againt him for religion, hee being of the Rominh perfwation) ${ }^{2}$ and is buried in Lanruthall church. He died upon $S^{t}$ Andrews day, (Nov: 30) of an ague año dñi 1616 . being a very healthy comely proper gentleman, as all that knew him ( $w^{\text {ch }} \mathrm{I}$ did not,) doe report of him. My grandmother Anne Lechmere dyed in January 1620 , at the houfe of $S^{r}$ Walter Blount of Sodington in this County, where thee was then upon a vifitt and is there buried; my grandfather and thee lived man and wife togeather 40 yeares and upwards. In theyr daies the eftate of our family receaved much diminution, occafioned (partly) by theyr religion (partly) by tedious fuits in law, efpecially $\mathrm{y}^{\mathrm{t}}$ for Bufhley park, but chiefly by theyr fuperfluous houfe-keeping.

“ My father Edmund Lechmere (onely foñe of Edmund ${ }^{3}$

1 Llanrothall or Llanfrother, in Herefordhire.

2 Probably from the intimacy with Bifhop Bonner.

3 The iffue of Edmund Lechmere and Anne Dyneley, according to the Hanley Regifter, was:-

" Edmundus Lechmere, bapt fuit xxii die Junii, 1577 .

"Helinor Lechmere, bapt $\mathrm{xxx}^{\text {mo }}$ die Augufti, 1579.

"Margeria Lechmere, bapt fuit xxi die Februarii, 1580."

Helinor appears to have died within the year.

“ Helinor Lechmere fepult fuit $\mathrm{iij}^{\text {to }}$ die Januarii 1579 " (80 ?). 


\section{House of Lechmere.}

his father) was borne the $19^{\text {th }}$ day of June 1577 , and in $y^{e}$ $19^{\text {th }}$ yeare of Q. Eliz: Hee tooke to his fecond wife (for he had a former wife $y^{e}$ daughter of one $M^{x}$ Blacknall of Abington in Barkfhire who died childleffe hortly after marriage) Margaret one of the daughters of $\mathrm{S}^{\mathrm{r}}$ Nicolas Overbury of Burton (Bourton) on the hill in the County of Glour Knight fifter of that famous $\mathrm{S}^{\mathrm{r}}$ Thomas Overbury who was poyfoned in the Tower of London. They married in June 1610 . the $10^{\text {th }}$ of October following was my Father admitted of the

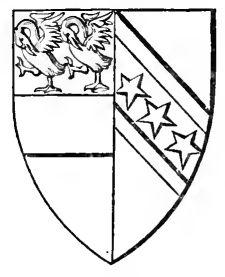
middle Temple. They had many children 8 foñes and 7 daughters of $w^{\text {ch }}$ Richard the eldeft was borne in June $1611,{ }^{1}$ and died 7. Aug. 1632. Hee was a hopefull handfome yong gentleman, bred up from Gloucefter Schoole in Queens Colledge in Oxford, and then in the Middle Temple London, where hee fickned but died at Hanley $\&$ is buried by his aunceftors. "They had allfo Edmund ${ }^{2}$ a yonger fone borne in Aug.

1 “ Ricardus Lechmere filius Edmundi Lechmere Gener: bapt fuit apud Borton Underhill fexto die Junii 1611 .

"Ricardus primogenitus Edmundi Lechmere gen : fepult fuit nono die Augufti Anō Dñi 1632."-P. R. Hanley.

2 According to a memorandum on paper pafted into the Judge's Book, and written apparently by the Judge's father, the children wcre:-

"Richard Leachmore, was baptized Junii 6, I6 II.

"Nicholas Leachmore, Oct 1, 1613.

" Edward Leachmore, Oct. 16, I614.

Lechmere, impaling, fable, three mullets in bend cotifed argent. Overbury. 


\section{Hanley and the}

I623. and died in London 4. Febr. I644. Hee was a very valiant yong man, thewing much bravery in divers fights betwixt $\mathrm{y}^{\mathrm{e}}$ king and parliam ${ }^{t}$ hee being firft an Enfigne, then ferving on horfeback, then as a Cap ${ }^{t}$ of foot for the parliam ${ }^{t}$. Hee died of a confumption contracted by hard duty in the warres, efpecially during his imployment $\mathrm{w}^{\mathrm{h}}$ Colonell Lytcott in the Ifle of Jerfey. hee dyed moft Chriftianly, and is buried in the Church of Saint John the Evangelift in London.

" My Mother $\mathrm{M}^{\text {rs }}$ Margaret Lechmere died of a confumption March. 14. 1634. and is buried in Hanley Church. ${ }^{1}$ She was a woman of a fingular underftanding, devout, and provident. thee dyed in the 42 yeare of her age. My father Edmund Lechmere dyed $y^{e}$ laft of July. 1650 . hee being then 73 yeares of age \& upwards, and is buried in Hanley Church in the very grave where my great grandfather was buried. Hee was a tall comely man, exceeding temperate in all things (but tobacco) and very kindly affectionat to his children. in his fickneffe ( $w^{\text {ch }}$ was nor long nor violent) hee behaved himfelf $\mathrm{w}^{\text {th }}$ much courage and exceeding cheerfullnes of fpiritt; being

“Anne Leachmore, Novemb. 27. I6I5.

“ Thomas Leachmore, Jan: 25. 1616.

"Margaret Leachmore, Jan: 18, 1620.

" Edmund Leachmore, Augt 21, 1623.

"Gen: chapter xlvii. the ix ${ }^{\text {th }}$ verfe. $M^{r}$ Woodfal's Text at the funerall of my poore soñe Richard Leachmore, buried the ix ${ }^{\text {th }}$ of Auguft, and died the viith of Auguft $16_{32}$."

1 “Margareta uxor Edmũdi Lechmere, filia Nicholi Overburi fuper montem milit: fepulta fuit quindecimo die Martii Anõ Dñi. I634." 


\section{Houfe of Lechmere.}

affured of his reconciliation $\mathrm{w}^{\text {th }}$ God through Chrift his Saviour. Hee left behind him at $\mathrm{y}^{\mathrm{e}}$ time of his death onely 2 foñes, Nicolas his heire and Thomas a Citizen of London. and fix daughters, Anne wife to Thomas Ruffell Efq ${ }^{\mathrm{r}}{ }^{1}$ Mary wife to $\mathrm{M}^{\mathrm{r}}$ Nicolas Short, Margaret wife to $\mathrm{M}^{\mathrm{r}}$ Mathew Smith of London, ${ }^{2}$ Elizabeth ${ }^{3}$ wife to Gabriel Yonge of Chobham in the County of Surrey Efq ${ }^{\mathrm{r}}$, and frances and Jane unmarried. (Jane afterwards married $\mathrm{M}^{\mathrm{r}}$ William Parfons, as appears by the following certificate: "Memorandum That a publication of confent of marryage between William Parfons of Tewkefbury, and $\mathrm{M}^{\mathrm{rs}}$ Jane Lechmere of Hanley, in the County of Worceiter, was made in the market place at Tewkelbury on the $17^{\text {th }}$ day of March 1654, and on two market days on the two next weekes following, and afterwards, that is to fay, on the $9^{\text {th }}$ day of Aprill I655, they were marryed \& declared Hufband $\&$ Wife by $\mathrm{M}^{\mathrm{r}}$ Lechmere, a Juftice of the Peace for the $\mathrm{C}^{\mathrm{y}}$ of Worceiter, in the prefence of $\mathrm{M}^{\mathrm{r}}$ Langfton, $\mathrm{M}^{\mathrm{r}}$ Warwick, minifter of Hanley \&c." 4 They both died in 1694, and are buried at Hanley.)

1 Thomas Ruffell was a younger fon of Sir Thomas Ruffell of Strenfham, in the County of Worcefter, Knt. The Marriage Articles are dated Aug. 8,1634 .

2 Whofe arms, according to a herald's work-book in the College of Arms, H. I, 63, were " $p^{r}$ bend indented or and az. two crofs patées countercbanged." They are nearly identical with thofe of Chriftopher Smith, clerk of the Pipe, in Grazebrook's “ Heraldry of Smith."

3 "She died 5 Jan: 1686, having been married 43 years, and was buried at Binfield, in Berks."-Cburcb Notes, College of Arms, T. T. 2 I, p. 29.

4 Bennett, "Hiftory of Tewkesbury," p. I86, note. 
Lechmere, impaling, or, $a$ fefs dancette between three crofs crollets, fitché gules. Sandys.

\section{Hanley and the}

"I Nicolas Lechmere third fone (the fecond fone died an infant) of Edmund Lechmere, by Margaret his wife was borne about the later end of Sept. 1613. the fame yeare and very neare the fame day that my Uncle $\mathrm{S}^{\mathrm{r}}$ Thomas Overbury was poyfoned in the Tower of London, I was baptized the $4^{\text {th }}$ of October. 1613. I was bred up in Gloucefter Schoole under $\mathrm{M}^{\mathrm{r}}$ John Langley a very worthy fchoolem $\&$ from thence about 15 yeares of age removed to Wadham Colledge in Oxford where I became a bacheler of arts, \& being full 20 yeares of age I was removed to the Middle Temple and

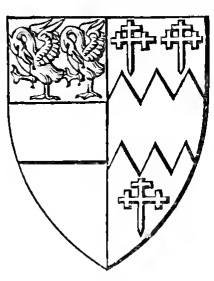
was called to the barr $4^{\text {th }}$ Jul. I64I. I 2. Nov. 1642. I (being then full 29 yeares of age) tooke to wife Penelope one of the daughters of $\mathrm{S}^{r}$ Edwin Sandys of Northborne in the County of Kent Knight by Katherine his wife one of the daughters of $\mathrm{S}^{\mathrm{r}}$ Richard Bulkeley of Anglefey Knight. I was married iuft one hundred yeares after my great grandfathers marriage, who was married in August I 542.

"The walke of elmes from $y^{e}$ garden to $y^{e}$ firft ftile was planted in $\mathrm{y}^{\mathrm{e}}$ yeare $\mathrm{I} 64 \mathrm{I}, \mathrm{y}^{\mathrm{e}}$ reft in $\mathrm{y}^{\mathrm{e}}$ yeare $\mathrm{i} 650^{1}$

"Auguft. 22. 1651. friday, the ${ }^{2}$ King with a

1 The greater part of thefe trees, forming a magnificent avenue, were cut down by Mr. Lechmere Charlton, eldeft fon of Edmund Lechmere, Efq., previous to the year 1830 ; they have been replanted with great tafte by the prefent Baronet.

2 Here are erafures of words which once probably conveyed fomething not very complimentary to His Majefty. 


\section{Houfe of Lechmere.}

numerous army, moft Scotts, fome Englifh, by long uninterrupted marches from Sterling (in Scotland) to Worcefter, fodainely poffeffed himfelf of the city of Worr, and in a few daies fortified it beyond imagination. At the fame time $y^{e}$ Scotts poffeffed themfelves of (and brake downe) Upton Bridge, Beawdley Bridge, Powick \& Brancefords bridges.

"Aug. 25. Maffie Major Gen. to $\mathrm{y}^{\mathrm{e}}$

1 King $\mathrm{w}^{\text {th }}$ about 130 Scottifh horfe quarter'd in my Houfe at Hanley, hee treated my people civilly, but threatned extirpation to mee and my pofterity bycaufe I was ioyn'd to the army of $y^{e}$ pliam ${ }^{\mathrm{t}}$.

"Aug. 27. I 50 Scotts horfe quarterd at my Houfe at Hanley.

"Aug. 28. the pliam" army under the comaund of the Lord Generall Cromwell advanc'd before Worcefter, and at $y^{\mathrm{e}}$ fame time Major Gen. Lambert gained Upton Bridge from the Scotts, in $\mathrm{w}^{\mathrm{ch}}$ enterprize Maffie was wounded and fome few of the enemy flaine.

"Aug. 29 the pliam" army drew clofe to the city of Worr.

"Sept. 3. 1651. it pleafed God to give a totall overthrow to this Scottifh army by his bleffing on the army of the pliam of England comanded by the Lord Generall Cromwell, the battell began on the weft fide the city (in thofe very fields where my brother-in-law Colonell Edwyn Sandys, the 23 of Sept. 1642 fought $w^{\text {th }}$ Prince Rupert and receaved the wounds

1 See note on page 16. 


\section{Hanley and the}

whereof afterwards (1. Dec. 1642) hee died) but was ended (and was harpeft) on the eaft fide.

"The Morning the battell was fought the Generall Cromwell made a bridge over the river of Severne (a little above Teme Mouth) and another bridge (clofe by) over the river of Teme, whereby hee paff'd over his army from fide to fide as hee faw occafion. The battell began about one of the Clock, lafted till night. I was prefent at it, in purfuit of the victory. the City of Wor $\tilde{r}$ was taken by ftorme, and all the wealth in it became booty to the fouldier."

(Three lines here erafed.)

"Adde hereunto, whiles I was imbroyled in thefe turmoiles here my wife was on Saturday (23. Aug. I651.) about twelve at noone fafely deliverd of a foñe whõ thee named Sandys. Thee was then at the Lady Pagets houfe in Deanes Yard Weftminfter.

" 4. July. 1648. I was by the inhabitants of Beaudley (nullo contradicente) chofen burgeffe to the parliament then fitting (in the place of $\mathrm{S}^{\mathrm{r}}$ Henry Herbert $\mathrm{k}^{\mathrm{nt}}$ difabled) and returnd by $\mathrm{S}^{\mathrm{r}}$ Thomas Rous Baronet high sherif of this county, and the $10^{\text {th }}$ of the fame July I was admitted into the houfe of Comons as burgeffe for Beaudley. ${ }^{1}$

“I 2. July. I654. I was chofen one of the Knights for the County of Worcefter, for the parliam ${ }^{\mathrm{t}}$ to bee held at Weft-

1 Here follows an account of his dealings with property in the parin of Ripple and Ryalls Court, which had been alienated to the Overburys. 


\section{House of Lechmere.}

minfter the 3. of Sept. following, John Barker Efq being then Sherif."

(The Judge then reverts to the earlier part of his life, and gives the following detailed account of the births of his children, by which we learn that from the year 1642 to 1655 he refided in London.)

"The time of my childrens births.

" I. I was married $y^{\mathrm{e}} 12$ of Nov. I642. $\mathrm{y}^{\mathrm{e}} 23$ of October I643, at $y^{\mathrm{e}}$ cock pitt in Saint James Park over againft white Hall my wife was delivered of a fone. Atill-borne. buried in $\mathrm{S}^{\mathrm{t}}$ Martins Church, to $\mathrm{w}^{\mathrm{ch}}$ parifh $\mathrm{y}^{\mathrm{e}}$ cock pitt belongs.

" 2. My daughter Letitia was borne at my brother Tho. Lechmeres houfe in friday ftreet Londõ the $19^{\text {th }}$ of January 1644 about 4 of $y^{e}$ clock in the morning, $\&$ named Letitia by the Lady Letitia Pagett, $y^{e}$ lady ffinch wife to $y^{e}$ lord keeper finch, and $\mathrm{S}^{\mathrm{r}}$ Henry Heyman.

“3. My foñe Edwin was borne at $y^{\mathrm{e}}$ fame place I. A pril. I646 \& named Edwin by Major Generall Maffie $M^{\mathrm{r}}$ Glynne recorder of Londõ and the lady Hanfhy.

“ 4. My daughter Penelope was borne at Weftminfter at $\mathrm{y}^{\mathrm{e}}$ lady Pagetts houfe in $\mathrm{y}^{\mathrm{e}}$ Deanes Yard there 29. Jul. I647. about 8 at night $\&$ was named Penelope by the lady Anne Harcourt, $\mathbf{M}^{\mathrm{rs}}$ Eliz. Sandys \& my brother Thomas Lechmere. ${ }^{1}$

1 She married, Sept. 27, 1664, Ralph Taylor, of Welland, gent., M.A. He died June 4, 1676, xt. 39. She died, May 29, 1710, æt. 62. Both buried at Welland, co. Worcefter. 


\section{Hanley and the}

"5. My fonne Edmond was borne at the fame place the $5^{\text {th }}$ of November 1648 . $\mathrm{w}^{\text {th }}$ in a quarter of an houre after fix in the morning. \& was named Edmond by Leycefter Lord Vifcount Hereford, $y^{\mathrm{e}}$ Lord Chief Baron Wylde \& $y^{\mathbf{e}}$ Lady Pagett.

“ 6. My daughter Katherine was borne at $y^{\mathrm{e}}$ fame place the 22 of March 1649 and was named Katherine by $M^{\text {ss }}$ frances Carr, $\mathbf{M}^{\mathrm{rs}}$ Pitts of Kyre, and General Edward Popham.

" 7. My fone Sandys was borne at the fame place the 23 . of Auguft I651. \& was named Sandys by $S^{r}$ Thomas Sandys $\mathrm{M}^{\mathrm{r}}$ John Sandys the Merchant \& my fifter Yonge.

" 8. My daughter Margaret was borne at the fame place Io. Nov. 1652. and was named Margarett by my fifter Smith $\mathrm{M}^{\mathrm{rs}}$ Margarett Carr and $\mathrm{M}^{\mathrm{r}}$ John Dormer.

"9. My foñe Thomas was borne at $y^{\mathrm{e}}$ fame place the $5^{\text {th }}$ of May ${ }^{16} 64$ \& named Thomas by $\mathrm{S}^{\mathrm{r}}$ Thomas Rous $\mathrm{M}^{\mathrm{r}}$ Thomas Overbury and $\mathrm{M}^{\text {rs }}$ Mary Acton.

"( (10.) My daughter Ifabella was borne at my brother Thomas Lechmeres houfe in Friday Atreet (for my hõ $b^{\text {le }}$ friend $y^{e}$ Lady Pagett died about June I655 upon whofe death wee (who had fojourned $\mathrm{w}^{\text {th }}$ her from the yeare 1646 till that time) removed to Hanley, but my wife comeing up to London Thortly after, was on $y^{\mathrm{e}} 2 \mathrm{I}^{\text {st }}$ of Auguit 1655 delivered of a daughter, named Ifabella by $\mathrm{y}^{\mathrm{e}}$ widow Lady Digby $y^{e}$ Lady Hantby \& $\mathrm{M}^{\mathrm{r}}$ Thomas Bulkeley.

"( (I) My daughter Mary was borne at my houfe at 


\section{Houje of Lechmere.}

Hanley in the chamber over the parlor the $29^{\text {th }}$ day of November 1656 about fix of $y^{\mathrm{e}}$ clock in the morning \& was named Mary by my coufin Edward Dingley of Charlton, my coufin Elizabeth Pytts \& my coufin Penelope Conliell." 1

" 20. Aug. 1656. I was chofen Knight of the fhire for this County of Worr for the parliam ${ }^{t}$ to bee held at Weftminfter the $I 7^{\text {th }}$ of Sept next following. Thomas ffoley $\mathrm{Efq}^{\mathrm{r}}$ then Sheriff."

(Next follows under date of $28^{\text {th }}$ June 1656 , an account of his purchafe of lands from the Coventry family, which I have omitted, and then follows a record of certain domeftic events.)

"The new kitchen $\&$ backhoufe $w^{\text {th }} \mathrm{y}^{\mathrm{e}}$ rooms over them were built by mee in the yeare 1656 the old buildings here before ftanding being by mee firft pulled downe.

"The accornes by the gate in the parke were fett between allhollowtide $(\mathcal{i} c)$ and chriftmas the fame yeare.

"The wall about $y^{\mathrm{e}}$ north part of the garden $\& y^{\mathrm{e}}$ houfe of office was built by mee in the year 1656 , and $y^{\mathrm{e}}$ wall about $\mathrm{y}^{\mathrm{e}}$ eaft part of $\mathrm{y}^{\mathrm{e}}$ garden in the yeare $\mathrm{i} 657$.

"Aug. 26. I657. betwixt nine \& ten in $y^{\mathrm{e}}$ morning dyed my very worthy kinfman Talbott Badger $\mathrm{Efq}^{\mathrm{r}}$. after a thort ficknefs of eight daies. hee was a worthy good man $\&$ an excellent holy Chriftian. In all the time of his ficknefs ( $\&$ foe of his health) I could not obferve one unadvifed word to

1 She married, April 23, 1685, Higham Coke, of Suckley, co. Worcefter, and died April 21, 1689, and is buricd at Suckley. 


\section{Hanley and the}

pceed from him, hee was much in fervent prayer \& dyed full of faith \& hope, uttering thefe his laft words in a triumphant tone, 'I am my beloveds and my beloved is mine, I come I come.'

"Hee was a Juftice of peace \& Capt of the horfe of this County, much beloved in his life \& much lamented at his death. An Excellent Example.

"This yeare 1657 very many dyed in this parifh of Hanley, to the number of at leaft forty prons, yet of noe peftilentiall or infectious difeafe, but of fundry maladies, \& among the reft foure children twins of one birth $y^{e}$ firft children of one good wife Hyde a yong woman at $y^{e}$ woodfide.

"In the year 1658 I built the weft \& fouth wall of the garden, \& the garden gate. The fame yeare I new built the north and fouth fides of the great barne, covering it all anew $y^{e}$ fouth fide with tile the north fide $w^{\text {th }}$ flatt.

"In feb. $y^{\mathbf{e}}$ fame yeare I planted the chefnutts in Upper Lechmere field.

(The Judge again recurs to political fubjects, and records the death of Cromwell and the proclamation of his fucceffor in the following terms.)

“ friday Sept. 3. 1658. This day \& yeare about 4 of $y^{e}$ clock in the afternoone at white-Hall dyed that ( erafed ) perfon Oliver Cromwell Lord Protector of England Scotland and Ireland having in his life time according to $y^{e}$ humble petition $\&$ advice of the laft preceding parliam ${ }^{t}$ declared his 


\section{Houfe of Lechmere.}

eldert fon the Lord Richard Cromwell his fucceflor who was the next day folemnely pclaimed in London \& Weftminfter \& throughout England $\mathrm{y}^{\mathrm{e}}$ weeke follow , fhortly after hee was pclaimed in Dunkirk then in the pofforn of the Englifh (won by his Father togeather with Mardike from the Spaniard in the yeare ${ }_{1658}$ ) The Lord Richard (now $L^{d}$ Protector) had the bleffing of a peaceable entrance upon the government."

(On a flip of paper, pafted in the book, is the following Invitation to Cromwell's Funeral which, as it is, if not unique, a very rare document, I have here tranfcribed; the original, except the addrefs, is printed.)

"Nicholas Letchmere Efq Attorney of the Duchy in yor Mourning Gowne $\&$ hood.

"You are defired to attend the Funeral of the moft Serene and moft Renowned Oliver late Lord Protector, from Somerfet-Houfe, on Tuesday the $23^{\text {th }}(\Omega i c)$ of November inftant at Eight of the clock in the morning at the furtheft, and to bring with you this Ticket; and that by Friday night next you fend to the Heralds Office near Pauls, the names of your Servants that are to attend in mourning, without which they are not to be admitted; and alfo to take notice that no coaches are to pafs that day in the Streets between SomerfetHoufe and Weftminfter." (Sealed with the fingle arms of Cromwell, a lion rampant, in red wax.)

\section{(Endorfed)}

"Recepi 18. Nov. 1658. N. Lechmere. No. 2." 
"In December following writs iffued for fum̃oning a pliam to meet at Weftminfter $27^{\circ}$ of January following. the $19^{\text {th }}$ of the fame Jan. was the day of election for this County, when in a very full county my felf \& Thomas ffoley $\mathrm{Efq}^{\mathrm{r}}$ were chofen $\mathrm{k}^{\text {nts }}$ for this thire. $\mathrm{y}^{\mathrm{e}}$ election was very coftly, the expenfe at feverall Innes in Worr (taken up by $M^{\mathrm{r}}$ foley \& myfelf for entertaynment of our friends) amounting to noe leffe then $(\Omega c)$ fix hundred $\&$ fourteen pounds, $w^{\text {ch }}$ wee payd to a peny. All this was occafioned by our competitors, $\mathrm{M}^{\mathrm{r}}$ John Talbott of Salwarp \& $\mathrm{M}^{\mathrm{r}}$ John Nanfan of BirchMorton ioyning agt $^{t} \mathrm{M}^{\mathrm{r}}$ Foley \& myfelfe. George Coventry Efq eldeft foñe to $y^{e}$ Lord Coventry then high Sherif.

"This pliam" lafted not long, but was by the impetuoufnes of the fouldiery difperfed on $y^{e}$ day of $1659 . \&$ fhortly after the old long pliam ${ }^{t}$ which had been interrupted the $19^{\text {th }}$ of April. $1653 . \&$ difcontinued to $y^{\mathrm{e}} 7^{\text {th }}$ of May 1659 then reaffembled, \& hortly after was Richard Lord Protector layd afide, his brother Henry Lord Lieutenant of Ireland comanded home, $\&$ both retiring to a private life, the pliam ${ }^{t}$ reftored the Govrnm ${ }^{t}$ in $y^{\mathrm{e}}$ way of a republike, as it was before the interruption.

"This fummer was an (erafed) infurrection made by $\mathrm{S}^{\mathrm{r}}$ George Booth \& $\mathrm{S}^{\mathrm{r}}$ Tho. Middleton in Lancafhire and Chefhire.

"This yeare 1659 I repaired Ryalls Court it being become very ruinous by long neglect $\&$ want of repations. it coft mee II $7^{1}$. 


\section{House of Lechmere.}

"I the fame yeare made $\mathrm{y}^{\mathrm{e}}$ wall frõ $\mathrm{y}^{\mathrm{e}}$ corne barne to $\mathrm{y}^{\mathrm{e}}$ parlor chimney. \& fet $y^{\mathrm{e}}$ furnace to brew $\mathrm{w}^{\text {th }}$ cole, of $\mathrm{w}^{\mathrm{ch}}$ the Iron work coft mee $2^{1} 14^{s}$. This fame yeare Sept. ult. my 2 girles Ifabella \& Mary came home frõ . . . . . .

"Thurfday. $25^{\text {th }}$ of Aug. 1659. I riding frõ Wor r to Monmouth Affizes a litle beyond $y^{e}$ old Gore ${ }^{1} w^{\text {th }}$ in a mile $\&$ half of Roffe, my horfe (by what accident I know not) tumbled over \& over, \& gave me a daingerous fall, in $w^{\text {ch }} I$ brake one bone in my left houlder $\&$ difplaced another, but by Gods bleffing in a hort time after well againe.

"Upon my return home my noble Cofin William Ligon Efq (being himfelf then removed frõ Maddresffield to Beauchamps Court for his health) fent mee this lire, with a poem compofed by himfelf much favouring of a devout holy mind. of $\mathrm{w}^{\mathrm{ch}}$ the title was The triumphs of Sion or the victory of Grace in fufferings. it was writ $w^{\text {th }}$ iudgment $\&$ elegancy. the dedication being to myfelf I here infert it Honoris ergo.

"To Nicholas Lechmere Efq".

$S^{r}$ though $\mathrm{y}^{\mathrm{r}}$ ferious thoughts frequent the barr where witt \& eloquence attended are

by gold \& honour, and the long robes thronge to catch $y^{e}$ nectar dropping frõ your tongue where the fage Judge lends you a patient eare $y^{\mathrm{e}}$ dark enigmaes of the law to cleere where power imployes your art $\mathrm{w}^{\mathrm{ch}}$ will not bec

I The old Gore is an inn by the road-fide, ftill, I believe, retaining its name and occupation. 


\section{Hanley and the}

by frownes or fmiles wrought to obliquity where injurd weaknes $\mathrm{w}^{\text {ch }}$ oppreflors grind your law \& learning for a patron find yet in receffes to your Tufculane if you have minutes for a thing foe vaine daigne here to read what gratitude hath fent, our love \& friendfhips lafting monument.

"Will Ligon."

"March, I6, I 659, $\mathrm{y}^{\mathrm{e}}$ long pliant (firft affembled by writ of King Charles $y^{\mathrm{e}}$ firft 3 Nov. 1640) after many wonderful changes by them made upon Church and State, \& many unprefidented alterations $\&$ impreffions made upon themfelves, as (frõ theyr firtt confiftence of King, Lords, \& Comons) acting by $\mathrm{y}^{\mathrm{e}}$ power of $\mathrm{y}^{\mathrm{e}}$ Lords $\&$ Comons whout $\&$ againt the king, $\&$ after by $y^{\mathbf{e}}$ power of $\mathrm{y}^{\mathrm{e}}$ Com̃ons onely (or rather a fmall part of the com̃ons) whout $\&$ againit $y^{\mathrm{e}}$ king $\&$ lords, \& after many interruptions of that remaining part of $\mathrm{y}^{\mathrm{e}}$ com̃ons, the firft by Oliver Cromwell, from the $19^{\text {th }}$ Apr : 1653 , to the $7^{\text {th }}$ of May 1659, and the other by Col : John Lambert \& other officers of $o^{r}$ Army from day of to $\mathrm{y}^{\mathrm{e}} \quad$ day of in the same yeare 1659 . This long pliamt the faid 16 of March 1659 , by act of its own diffolved itself. But before the Diffolution an act was made by them for affembling another pliañt $25 \mathrm{Ap}: 1660, \mathrm{w}^{\mathrm{ch}}$ affembled accordingly. note $\mathrm{y}^{\mathrm{e}}$ comons were fum̃oned by writ under $\mathrm{y}^{\mathrm{e}}$ then great feale, under $y^{e}$ ftyle of $y^{e}$ keepers of $o^{r}$ liberty (a name invented by the long pliam̃t, after they had declared themfelves a republic) and noe writs at all iffued for sumon- 


\section{Houfe of Lechmere.}

ing of the peeres, but they affembled gratis, and acted as a houfe of peeres."

(The different tone between this laft part of the writer's Journal and the former, is evident; the fact is, he had wifely perceived the figns of the times, and had applied for, and obtained pardon for his former demerits. This appears from his Journal, and alfo from a letter from Lord Vifcount Mordaunt to the King (Charles II.), preferved in Lord Clarendon's State Papers, ${ }^{1}$ which is as follows :-

$$
\text { "March 24, } 1660 .
$$

"I become an humble fuitor to your Majefty, in behalf of one who faved my life at the High Court of Injuftice, Mr. Lechmere, who was never in any of thofe Courts before, $\&$ there endeavoured to fave us all; $\mathrm{He}$ is now confiderable in his country: being Commiffioner of the Militia in Shrophire, Hereford \& Worcefternhire; His intereft he will employ as I fhall direct, in placing fuch Captains of Horfe \& Foot in command there as I thall propofe to him. He has drawn up his pardon himfelf, a copy of which will be ufeful to lay by your Majefty for a precedent: He likewife pays $£ 200$ for it ; it is a good example to induce others to return betimes to their duty; and being all thofe, who never were engaged in the molt perverfe of all actions, are pardoned by the Proclamation, it is certainly more to your majefty's fervice to forgive particular perfons who repent and feek pardon thus fingly, than 


\section{Hanley and the}

to forgive all in grofs; The money I will return when your Majefty commands it, and hope great numbers will follow in this kind; it were to be wifhed all men would be taken off thus, except the excepted in the proclamation."

[The Journal hence proceeds in the following loyal terms.] "Note, that May 29, [1660] the moft excellent Prince Charles $y^{\mathrm{e}}$ fecond King of England $\&^{\mathrm{c}}$ came to London, hee having been moft injurioufly deprived of his kingdomes \& governñt ever fince $\mathrm{y}^{\mathrm{e}}$ death of his father Charles ye firft, $\mathrm{w}^{\mathrm{ch}}$ was 30. Jan: I648. to that time. Hee landed at Dover fome few daies before, pafs'd frõ Dover to London in continued throngs \& houts of people flocking frô all parts of $o^{r}$ nation $\&$ was recđ by the greateft joy $\&$ heart-fatisfaction that foe long defired \& foe worthily deferving a prince could bee. After $y^{e}$ diffolution of the long pliament, of $\mathrm{w}^{\mathrm{ch}} \mathrm{I}$ was an unhappie member, I applied myfelf to his $\mathrm{Ma}^{\text {tie }}$ then at Bruxells for his Pardon, $\mathrm{w}^{\text {ch }}$ his $\mathrm{Ma} \mathrm{a}^{\text {tie }}$ afterwards, at Breda, $\mathrm{y}^{\mathrm{e}} 4^{\text {th }} \mathrm{Apr}$ : I 660 moft gracioufly granted mee, \& I hortly after recđ it under $y^{\mathrm{e}}$ great Seal of England. my chief inftrument in procuring it was the right hõble John $\mathrm{L}^{\mathrm{d}}$ Vifcount Mordant by the mediation of my moft fincere ( $\&$ therefore moft honoured) friend Thomas Beverley Efq: now $\mathrm{S}^{\mathrm{r}}$ Thomas Beverley $\mathrm{K}^{\mathrm{nt}}$. "Apr: 22, I66I. His Ma ${ }^{\text {tie }}$ was crowned at Weitminfter, the pompe \& folemnity of whofe coronation was exceeding great \& magnificent.

"In the yeare I66 I, I built the flood gate, \& the fame yeare I built my ftudy at the fouth wert end of the garden at Hanley. 


\section{Houje of Lechmere.}

"In the yeare 1662 , I finifhed $y^{\mathrm{e}}$ mount walke, $\mathrm{y}^{\mathrm{e}}$ ftone work was done by Goddard of at $y^{\mathrm{e}}$ rate of fixpence a foot for $y^{e}$ coping, and $4^{d} y^{e}$ foot for $y^{e}$ ftepps, Hee found $\mathrm{y}^{\mathrm{e}}$ ftone, wrought and layd it at $\mathrm{y}^{\mathrm{t}}$ rate, I paying for $\mathrm{y}^{\mathrm{c}}$ carriage.

[Next follows a note of a Trial at Worcefter, with regard to a cuftom within the parifh of Hanley, as to the payment of $2 d$. a hogfhead for Impropriate Tithe; the Jury found there is fuch a cuftom.]

"July $9^{\text {th }} \mathrm{I} 663$, my daughter Katherine, after a long weakneffe departed this life, and lieth buried in the Inle in Hanley Church, next to my great grandfather, between his grave and the font. ${ }^{1}$

"This yeare I new built $y^{\mathrm{e}}$ cart houfe at $\mathrm{y}^{\mathrm{e}}$ end of the great barne.

"June 1 8, 1664, a feale or fea calf (vitulus marinus) was killed in Seaverne towards $y^{\mathrm{e}}$ upper end of Seaverne meadow in Hanley. This firh was about 7 foot in length, $8 x$ was killed in the river by one William Teale of Hanley $w^{\text {th }}$ a mufket fhott.

[The next entry in the Journal relates to the Manor of Eftington, purchafed from Richard, Earl of Dorfet, in the years 166I-I664. He fums up as follows.]

" and foe now all titles are united in mee, and I hope God will bleffe it to mee $\&$ my pofterity after mee. Amen."

1 "July ye $8^{\text {th }}{ }_{16} 66_{3}, M^{\text {s }}$ Katherine Lechmere daughter of $\mathrm{M}^{\mathrm{r}}$ Nicholas Lechmere and Penelope his Wyfe, buried."-P. R. Honley. N.B. Either an error in this date or in the Judge's Journal as to the 8th and 9 th. 


\section{Hanley and the}

"March 2, I664. My cofin ${ }^{1}$ Roger Lechmere of Fanhope dyed whout iffue, $\&$ by his laft will devifed his mannor houfe at Fanhope, $\&$ moft of his lands here to his wife, $\&$ after to mee $\&$ my heires, but charged $w^{\text {th }}$ a great fume.

" March 4, I664. My cofin Richard Lechmere Uncle \& next heire to Roger, being difpleafed $\mathrm{w}^{\text {th }} \mathrm{y}^{\mathrm{e}}$ will (as indeed he had caufe, being Uncle and next heire, \& yet not mentioned in it) \& allfo to expreffe his kindnes to mee $\&$ my family, did execute a deed of covenant to mee, whereby he did covent to ftand feifed of that eftate here to $y^{e}$ ufe of mee for my life, $8 x$ 2I yeares after, $\mathrm{w}^{\text {th }}$ divers remainders over to my children, only he referved an Eftate for his own life in fome $\mathrm{p} \tilde{\mathrm{t}}$ as he well deferved.

" this deed is of great ufe, for whereinfoever $y^{e}$ will of Roger is eneffectuall, as I think it is to $y^{e}$ maine, this deed will doe it $w^{\text {th }}$ effect $\&$ whout $y^{\mathrm{e}}$ charge upōn it, $w^{\text {ch }} y^{\mathrm{e}}$ will has layd."

[The cautious old lawyer has added here]- " not foe I find." "April 6, 1665. my fone Edmund was admitted into Trinity Coll : in Oxford, a Gentleman Comoner of that Society : \& next day went into Com̃ons. One $\mathrm{M}^{\mathrm{r}}$ Nicholas Stratford (a difcreet man) being his Tutor; And inftead of plate I gave ten pounds to $y^{e}$ houfe in money to bee imployed in theyr new building, this I did at the requeft of $y^{e}$ Society,

1 Roger Lechmere of Fanhope was defcended from Roger, fecond fon of Thomas Lechmere of Hanley and Elianor Frere. 


\section{Houfe of Lechmere. 1487979}

\& of this gift of mine, there is a memoriall enter'd in $y^{e}$ Ledger booke of that Society.

"On Wenfday Jan: 27, I665, my worthy friend \& kinfman $S^{r}$ Thomas Rous of Rous-Lench Bart: came to my houfe \& brought $\mathrm{w}^{\text {th }}$ him in company William Ferrers Efq, a young gent : of 25 yeares of age, \& a kinfman of $\mathrm{S}^{r}$ Tho: Rous his former lady (he was $y^{e}$ daughter of $S^{r}$ Humfrey Ferrers of Tamworth Caftle) this gentleman hee kindly brought to my houfe to bee a fuitor to my eldeft daughter Letticia. The Wenfday following I fet forward for $\mathrm{y}^{\mathrm{e}}$ circuit $\mathrm{w}^{\mathrm{ch}}$ began at Abington, Jul: 7 1665. leaving $\mathrm{M}^{r}$ Ferrers at my Houfe.

"Thurfday I 3 Jul: $\mathrm{M}^{\mathrm{r}}$ Ferrers came to me to Worr being $y^{e}$ day before $y^{e}$ affizes there. Wherein through prefence of my worthy cofin Edward Dingley of Charlton Efq. wee quickly agreed $\mathrm{y}^{\mathrm{e}}$ marriage.

"Monday I7 Jul: $\mathrm{M}^{\mathrm{r}}$ Ferrers came to me to Stafford, \& from thence accompanied me to Shrewfbury : Wenfday $9^{\text {th }}$ of Aug : $y^{\mathrm{e}}$ circuit ended at Glour : $w^{\mathrm{ch}}$ day I came home, $\&$ found $\mathrm{M}^{\mathrm{r}}$ Ferrers at my Houfe, where he had continued a weeke before.

"Monday I 4 Aug : wee fealed $y^{\mathrm{e}}$ marriage agreement, \& $\mathrm{y}^{\mathrm{e}}$ wedding day was intended to bee tuefday $\mathrm{y}^{\mathrm{e}} 29^{\text {th }}$ of Auguft, $w^{\text {ch }}$ day $M^{r}$ Ferrers inclined to bycaufe on that day, as he fayd, his father was married.

“Wenfday $y^{\mathrm{e}}{ } 6^{\text {th }}$ of Aug : $\mathrm{M}^{\mathrm{r}}$ Ferrers went frõ my houfe to fetch his Mother to his wedding, the was then at Stanton in Leicefterhire, at $y^{\mathrm{e}}$ houfe of one Richard Brudenell Efq 


\section{Hanley and the}

who had married her fifter's daughter, the daughter of $\mathrm{S}^{\mathrm{r}}$ Walter Littleton of Lichfield by his lady $y^{e}$ fifter of $M^{\text {rs }}$ Ferrers, they were both of them $y^{e}$ daughters of $S^{r}$ Lewis Pemberton.

"Saturday I9: Aug: $M^{r}$ Ferrers came to Stanton, \& that night was not well. complayning of great paine in his head. foe he continued till Thurfday night $\mathrm{I} 2$ oclock, at $\mathrm{w}^{\text {ch }}$ time, hee fell into a Lethargie, in which he continued till Monday following.

"Sunday 27: Aug : I had notice of his ficknes by a letter frõ his Mother.

" Monday $28^{\text {th }}$. I fet forward for Leicefterfhire \& came to Stanton $\mathrm{y}^{\mathrm{e}}$ day following, when I found $\mathrm{M}^{\mathrm{r}}$ Ferrers alive, but paft hope of recovery: The Phyficians $\mathrm{D}^{\mathrm{r}}$ Bowles $\mathrm{D}^{\mathrm{r}}$ Tyringham $\& \mathrm{D}^{\mathrm{r}}$ Moore being all gone, as iudging his life defperate : \& foe it proved to my great forrow, for on Wenfday following about 5 in $\mathrm{y}^{\mathrm{e}}$ afternoone hee dyed, $\& \mathrm{w}^{\text {th }}$ him dyed as worthy a yong gentleman as ever I was acquainted $w^{\text {th }}$. Hee was a right honefte man, of great parts \& learning, every way accomplifhed $\mathrm{w}^{\text {th }}$ travaile languages mufick etc: Hee was of $y^{e}$ barre in Grayes Inne, \& a good proficient in $y^{e}$ Lawes, $\mathrm{w}^{\text {ch }}$ hee intended his pfeffion. Hee is buried in $\mathrm{y}^{\mathrm{e}}$ church at Stanton on $y^{e}$ right hand of $y^{e}$ Quire. ${ }^{1}$

" My poore Daughter tooke her loffe, as thee had juft caufe,

1 “Will Ferrers Efq was buried Auguft the laft 1665."-P. R. Staunton Wyvile. 


\section{House of Lechmere.}

$\mathrm{w}^{\text {th }}$ exceeding forrow; but I truft God has a bleffing in ftore for her, notwithftanding this great difappointint. fiat voluntos Domini. ${ }^{1}$

"This yeare (1665) was a very great mortality in Lond $\&$ all places thereabouts. there dyed about July \& Aug : many thoufand weekely.

"this year Upton was infected, it began in the houfe of Phillip Sermon, \& divers of his family dyed of it, $\&$ in fome few other houfes.

"This yeare I fet $y^{e}$ Elms in the upp end of the KeyMeadow, Seris factura nepotibus umbram.

"Aug: 1666. I pchafed of Thomas frewen his houfe and land it coft me $470^{\prime}$. being $70^{1}$. too deare, but fome conveniency made mee over-buy it.

"This yeare $\mathrm{y}^{\mathrm{e}}$ City of Londõ was deftroyed by fire, the fire began 2. Sept: 1666, near Londõ bridge \& in three daies time confumed all from thence to $\mathrm{y}^{\mathrm{e}}$ Temple, $\& \mathrm{w}^{\mathrm{h}}$ it a great pt of $y^{e}$ Temple, fpreading to Aldgate, Alderfgate, $\&^{\mathrm{c}}$. foe that little of $\mathrm{y}^{\mathrm{e}}$ City remained unburnt, befydes much of $y^{e}$ fuburbs burnt. The hande of Joab was thought to bee in it, but time will difcover.

"This yeare I made the inclofure in Northfield \& planted $\mathrm{y}^{\mathrm{e}}$ quick-hedge there-the rick clofe.

"Eafter Terme 1667 my foñe Edmond came into Counons in the Middle Temple. Benedicat Deus.

1 She never married, but died in October, 1669. 


\section{Hanley and the}

" July 27, 1667. dyed that very worthy \& excellent pfon $\mathrm{M}^{\mathrm{r}}$ Henry Bromley of Upton, a pfon certainely of fingular virtue $\&$ piety, $\&$ of rare endowments of nature."

(Next follows a note dated in 1668, with regard to the purchafe of " $y$ reverfion of Rogers-Meadow, lying in Seavern Meadow, pcell of the Mannor of Hanley Hall," from the Ruffell Family; and here appears to be the proper place to infert the following interefting letter, the original of which is preferved in the Judge's Book, and which was written while he was on Circuit, being then a rifing Barrifter, at Shrewfbury, March 20, I668.)

" ffor my dearly beloved foñe Edmund Lechmere.

" Ned : $y^{\mathrm{e}}: 23$ day of March approaching (on $w^{\mathrm{ch}}$ day now one hundred yeares agoe my great grandfather dyed) I have often thought I fhould not furvive it, and though I am now, (God be bleffed) in pfect health \& ftrength, yet I think fit to fet down thefe few memorialls.

" $\mathrm{I}$. in cafe I dye let mee be buried privately in $\mathrm{y}^{\mathrm{e}}$ night whout any pompe or folemne funerall, in $y^{e}$ place I formerly appointed.

" 2. I have made my will allready, \& put it in my garden ftudy in one of the drawers there. $y^{\mathbf{c}}$ key of thofe drawers \& of my iron cheft you will find in $\mathrm{y}^{\mathrm{e}}$ woodden box in $\mathrm{y}^{\mathrm{t}}$ ftudy.

" 3 . I have made you my fole Executor for $\mathrm{w}^{\mathrm{ch}}$ you are of age fufficient. my will muft bee proved in the Prerogative Court of Canterbury by reafon of my bona notabilia in divers dioceffes. 


\section{Houje of Lechmere.}

" 4. after my death take care of payment of my debts \& $\mathrm{y}^{\mathrm{r}}$ fifters portions ; \& of your owne $\& \mathrm{y}^{\mathrm{r}}$ brothers education.

" 5 . doe not marry too foone, $\&$ when you doe, marry into fome worthy family where religion fobriety $\&$ vertue is owned, \& make not too great a ioynture, for that is pnicious to families.

" 6 . doe not forfake $y^{\mathrm{e}}$ Temple nor your ftudyes there, $\&$ let your company bee $w^{\text {th }} y^{\mathrm{e}}$ fober $\&$ ingenious gentlemen of that $\&$ other Societies.

" 7. exercife $y^{\mathrm{r}}$ difcretion foe as that you bee not a prey to knaves \& cheates, neyther in $\mathrm{y}^{\mathrm{r}}$ marriage nor $\mathrm{y}^{\mathrm{r}}$ other converfation.

" 8. Let your brother bee removed now at Eafter next to $\mathrm{y}^{\mathrm{e}}$ Univerfity \& there placed a Coñoner (and noe higher) under fome Tutor of $\mathrm{M}^{\mathrm{r}}$ Colliers recom̃endation, \& take care $\mathrm{y}^{\mathrm{t}}$ hee live foberly modeftly $\&$ vertuounly in $\mathrm{y}^{\mathrm{e}}$ Univerfity, and when hee hath continued there one whole yeare remove him to $\mathrm{y}^{\mathrm{e}}$ Temple (where hee is allready admitted) \& fee $\mathrm{y}^{\mathrm{t}}$ hee follow his Atudyes diligently $\&$ live foberly modeftly $\&$ vertuoufly $\&$ in due time take upon him $y^{\mathrm{e}}$ profeffion in which I have gone before him, \& I require this $y^{\mathrm{e}}$ rather of him, bycaufe I think him well fitted for $\mathrm{y}^{\mathrm{t}}$ pfeffion.

" 9. for $y^{r}$ fifters bee kind to them \& Atudy theyr advancemt according to $y^{e}$ portions I have left them by my will, $\&$ if they marry $\mathrm{w}^{\text {th }} \mathrm{y}^{\mathrm{r}}$ or $\mathrm{y}^{\mathrm{r}}$ mothers liking give each of them (if you can) $100^{1}$ more than $I$ have given them.

" 10 . Bee dutifull unto $\&$ tender of $y^{x}$ Mother $\&$ bee a com- 


\section{Hanley and the}

fort to her when I am gone, \& that you may bee mutuall comforts to one another all extravagant expences muft be avoided, $\&$ all pties muft content themfelves $w^{\mathrm{h}}$ what is left them.

"II. noe heriot is due upõ my death for any $\mathrm{p}^{t}$ of my eftate, but onely for Hanley, \& for that onely one heriot by the cuftome of $\mathrm{y}^{\mathrm{e}}$ place. Eftington comes to you by furvivorhip, Ryalls Court \& Lulfey are not heriotable, but reliefs muft be payd for Hanley \& Ryalls Court \& for noe other.

“ I2. Remember $y^{t} y^{e}$ eftate left you was (the greateft part of it) gained by $y^{e}$ induftry of $y^{r}$ father, $\&$ if you cañot increafe it yet if you doe not preferve it you will bee blameworthy. but looke upõ Gods bleffing as your beft patrimony $\&$ doe not by a vicious life pvoke his wrath agt you.

" 13 . Bee pitifull \& compaffionate to $y^{e}$ poore, $\&$ think not what is parted $\mathrm{w}^{\text {th }}$ to fuch to bee loft, but layd up for you $\&$ yours.

"Thefe Memorialls I thought fit to leave for you (not as part of my will or to be annexed to it) but as directions and inftrucôns in $y^{e}$ future courfe of your life, $\&$ as a teftimony of $\mathrm{y}^{\mathrm{e}}$ fatherly love I beare you, \& foe recomending you to $\mathrm{y}^{\mathrm{e}}$ guidance of $\mathrm{y}^{\mathrm{e}}$ Allmighty $\mathrm{w}^{\text {th }}$ my bleffing upõ you $\&$ all $\mathrm{y}^{t}$ fifters \& brothers I reft $\mathrm{y}^{\mathrm{r}}$ very loving Father.

$$
\text { "N. Lechmere." }
$$

"March 20, 1668. Shrewfbury.

Io guineas in my pocket."

(To recur again to the Journal.)

“ This yeare (I668.) I made $y^{e}$ cellar under $y^{e}$ buttry $\& y^{e}$ 


\section{Houje of Lechmere.}

chimneys adjoyninge, \& made $\mathrm{y}^{\mathrm{c}}$ front of the whole new between the Hall chimneys \& thofe new chimneys. cü multis aliis.

"March I, I668. I enterd upồ my reading in $\mathrm{y}^{\mathrm{e}}$ middle Temple. I read upõ $y^{t}$ branch of $y^{e}$ ftat. of $33, \mathrm{H}$. VIII. cap : $39 . \mathrm{w}^{\mathrm{ch}}$ fubjects eftates tayle to $\mathrm{y}^{\mathrm{e}}$ Kings debts by iudgment recognifans obligar : over other fpecialty. I read (I thank God) with good acceptation. but it cort mee many hundred pounds.

"On $y^{\mathrm{e}}$ I ${ }^{\text {th }}$ of feb: before dyed my honeft fervant Samuel Bucke yongeft foñe of Gervafe Bucke Efq: \& Grandfon of $\mathrm{S}^{\mathrm{r}}$ John Buck $\mathrm{K}^{\mathrm{nt}}$ hee lieth buried at $\mathrm{y}^{\mathrm{e}}$ Temple. hee was an honeft underftanding man $\&$ had ferved mee many yeares.

"This yeare at my goeing up to Eafter terme I placed my fone Sandys a Comoner in Chriftchurch in Oxford, $\mathrm{M}^{\mathrm{r}}$ Collier his Tutor. God guide him. ${ }^{1}$

"This yeare 1669 in June my foñe Edmund went into fraunce $\&$ returned in Auguft following.

"This yeare Oct. 7. dyed my deare daughter Letitia: $\mathrm{S}^{r}$ Thomas Overbury having been here in Sept before, thee accompanied him \& his Lady back to Bofton \& there fell fick $\&$ dyed. Thee is buried in Bofton Church in $y^{\mathrm{e}}$ chancell there.

"This yeare I planted $\mathrm{y}^{\mathrm{e}}$ orchard in litle Longcroft.

"This yeare I contracted for Cowley parke, am to pay for it two thoufand three hundred fiftie five pounds.

"This yeare Jan: 3. dyed George Duke of Albemarle, who

${ }^{1}$ He was the anceftor of the prefent family of Lcchmere of Fanhope. 


\section{Hanley and the}

being from an ordinary officer raifed by Cromwell to bee Governor of Scotland had thereby $y^{e}$ happy opportunity of being the chief inftrument of his $\mathrm{Ma}^{\text {tyes }}$ reftoration. ffor $\mathrm{w}^{\text {ch }}$ laden $\mathrm{w}^{\text {th }}$ honours $\&$ wealth hee for nine yeares $\&$ upwards inioyed the fruit of his own great defervings, togeather $\mathrm{w}^{\text {th }}$ the fingular favour of a moft munificent $\&$ gratefull Mafter.

"This yeare in Dec : ${ }_{1669}$. S Richard Sandys $K^{\text {nt }}$ (eldeft foñe of Edwyn Sandys Efq eldeft foñe of $S^{r}$ Edwyn Sandys my wifes father) being a birding neare his houfe at Northburne in Kent the gunne in his hand went off unexpectedly $\&$ thott him dead in $y^{t}$ place.

“ This yeare II. March. I669. my very loving brother $\mathrm{M}^{\mathrm{r}}$ Thomas Lechmere departed this life at Totteridge in Hartfordhire $\&$ is buried in the church there. Hee was a worthy good man of a bountifull heart $\&$ hand, a wife iuft honeft man \& truely religious. Hee left nine children, foure foñes Thomas ${ }^{1}$ Nicholas $^{2}$ Edmund \& Richard $^{3} \&$ five

1 Thomas, the eldeft fon, doubtlefs the Thomas Lechmere who married at Weftminfter Abbey, Dec., 1677, Jane Blagrave. He died in 1703 . See Col. George Chefter, “Weftminfter Abbey Regifters," p. I 5.

2 Nicholas, 2nd fon of Mr. Thomas Lechmere, by his wife Anne, was alfo a merchant of London, and married Judith, fole daughter and heir of John Corbett, late of Alfton, in the County of Salop, Efq. He appears to have been father of Richard Lechmere, of Sutton Hall, London, living Dec., 1 738, and grandfather of Prebendary Lechmere, who died Prebendary of Winchefter in 1770 .

3 Was this the Richard of Newborne Hall, co. Suffolk, whofe fon Thomas was buried at Bermondfey in 1778? See Lyfon's " Environs of London," vol. i., p. $55^{1}$. 


\section{Houfe of Lechmere.}

daughters $\&$ a difcreet vertuous widow behind him. hee was 53 yeares old \& fome weekes, being baptized $y^{\mathrm{e}} 25^{\text {th }}$ of Jan: I6 6.

"Año I670, in Eafter terme dyed $\mathrm{M}^{\mathrm{r}} \mathrm{W}^{\mathrm{m}}$ Sandys yonger fone of $\mathrm{S}^{\mathrm{r}} \mathrm{W}^{\mathrm{m}}$ Sandys of Miferden in $\mathrm{y}^{\mathrm{e}}$ county of Glour. this was that $\mathrm{Mr}$. Sandys that made $\mathrm{y}^{\mathrm{e}}$ river of Avon navigable, $\&$ wafted a fine eftate in that undertaking $\&$ others of $\mathrm{y}^{\mathrm{e}}$ like nature.

"This yeare in $y^{e}$ moneths of July. Aug. \& Sept. I built the new brick Atable.

"This yeare in Eafter terme my foñe Sandys came into Com̃ons in $\mathrm{y}^{\mathrm{e}}$ Middle Temple.

"January 12. 1670. my daughter Margaret was married to Edmond Neale of London Efq. ${ }^{1}$

"In hilary terme following I fold $\mathrm{y}^{\mathrm{e}}$ water flade $\&$ other lands at Lulfey to $\mathrm{M}^{\mathrm{r}}$ Winnington.

"In febr. March \& April I670. \& I67I. I built the new barne at Ryalls Court. April I67 I. I fold a fmall pcell of land in Tucks end in $y^{\mathrm{e}}$ pifh of Earles Crombe to one Bromage.

“I 5. Dec. I671. My cofin $M^{\text {ss }}$ Anne Lechmere of Fanhope (widow \& relict of my kinfman $M^{r}$ Roger Lechmere

1 The P. R. of Hanley fays, Jan. 10, 1670.

Edmund Smith, one of the minor poets of England, is faid to have been the fon of this Edmund Neale and Margaret Lechmere, and to have been born near Tenbury in 1668, and to have adopted the name of Smitb from the kindnefs of a relation. If born 1668 , he was probably the fon of Mathew Smith and Margaret Lechmere, the Judge's fifter. 


\section{Hanley and the}

deceafed) receaved a bruife in her head by $y^{\mathrm{e}}$ overturning of her coach of $\mathrm{w}^{\mathrm{ch}} \mathrm{w}^{\text {th }}$ in few houres the dyed. whereupo that eftate there fell to mee, but charged $\mathrm{w}^{\text {th }} 2200^{1}$ to bee payd by mee as thee fhould direct. this thee prevailed $\mathrm{w}^{\text {th }}$ her hufband to charge $\mathrm{y}^{\mathrm{t}}$ eftate withall ( $\mathrm{w}^{\mathrm{ch}}$ was not well done I believe) but the burthen is fallen upon mee $\&$ I muft beare it.

"Sept. 25. I672. I pchafed of $\mathrm{M}^{\mathrm{r}}$ Horniold the perpetuall advowfon of the vicaridge of Hanley \& $x$ a releafe of all tenures cuftomes and fervices for my lands in Hanley this coft $200^{1}$.

" 1673 . This yeare I began the brick building on the north $\&$ fouth fide $\mathrm{y}^{\mathrm{e}}$ green court. one $\mathrm{M}^{\mathrm{r}}$ John Averian(?) undertooke $\mathrm{y}^{\mathrm{e}}$ whole $\&$ to provide all materialls and make it fit for habitation for $250^{1}$. how hee will performe time will fhow.

"He fayled in all things.

"Aug. 7. 1673. My foñe Edmund married $M^{\text {rs }}$ Lucy Hungerford yongeft fifter of $S^{r}$ Edward Hungerford of ffarley

Lechmere, impaling, fable two bars argent, in chief three plates. Hungerford.

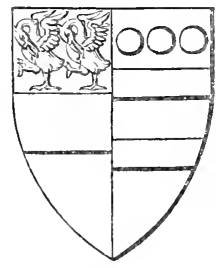

Caftle in the county of Somerfet Knight of the Bath, a perfon honourably defcended from $y^{e}$ auncient Atock of $y^{e}$ Hungerfords Barons. but by feverall attainders and by the marriage of Mary Hungerford daughter $\&$ heire of Thomas Lord Hungerford Botreaux \& Molines to Edward Lord Haftings (frõ whom $y^{\mathrm{e}}$ Earles of Huntington are defcended) the family is at this day devefted of their auncient place amongt the 


\section{Houfe of Lechmere.}

peeres in parliament, but a family ftill continuing in the next rank to $y^{\mathrm{e}}$ nobility. my daughter-in-law feemes to bee a fober worthy yong woman, \& my fone (probably) moft happy in her. But folus barum rerum Laudator Tempus.

"The marriage was folemnized at Black Borton (Bourton) in Oxfordfhire being $\mathrm{y}^{\mathbf{e}}$ ioynture houfe of $\mathrm{y}^{\mathrm{e}}$ widow lady Hungerford $y^{\mathrm{e}}$ mother. where noe coft was fpared, indeed there was much needlefs expenfe, but the mother would have it foe. There were prefent at $y^{\mathrm{e}}$ marriage $\mathrm{y}^{\mathrm{e}}$ Lady Mother, $\mathrm{y}^{\mathrm{e}}$ Lord \& Lady ffalkland \& one $\mathrm{M}^{\mathrm{r}}$ Cary their kinfman, $\mathrm{S}^{\mathrm{r}}$ Edward Stradling of $\mathrm{S}^{t}$ Donates in Glamorganfhire \& his lady, $S^{r}$ Thomas Overbury $S^{r}$ Robert Henley of the Grainge neare Winchefter \& his lady $\mathrm{M}^{\mathrm{r}}$ Mountagu of Laycock in Wilthire \& his lady, $M^{r}$ Dingley of Charlton, the great $M^{r}$ Sheldon of Wefton ${ }^{1} \&$ many with him, myfelf, wife, daughters, Kate Bell \& Mall Sifter Smith, nephew ffleetwood cum multis alijs. my Lord Falkland \& $\mathrm{M}^{\mathrm{r}}$ Hungerford eldeft foñe of $\mathrm{S}^{\mathrm{r}}$ Edward were bridemen, my daughter Bell and one Madam Warnford Bridemayds. $\mathbf{M}^{\mathrm{r}}$ Sheldon of Wefton \& myfelf led the old Lady to her coach \& waited upon her to church where $\mathrm{M}^{\mathrm{r}}$ Sheldon continued all $\mathrm{y}^{\mathrm{e}}$ folemnity. after that ended $\mathrm{y}^{\mathrm{e}}$ bride was delivered to $\mathrm{M}^{\mathrm{r}}$ Sheldon \& myfelf, who led her to her coach, \& waited upon her home. Benedicat Deus. Amen. Amen.

1 This was Ralph Sheldon, of Beoley and Wefton, Efquire, who died in 1684 . 


\section{Hanley and the}

"Wenfday I7 June I674 my daughter Lechmere was delivered of a foñe at her Mothers houfe in Oxfordhire, hee was named Anthony according to $y^{e}$ name of his grandfather Hungerford. Benedicat Deus. Amen.

"Aug. 5. 1675. about I2 or one at night my daughter Lechmere was deliverd of a fonne at my houfe at Hanley, hee was named Nicholas according to $y^{e}$ name of his Grandfather Lechmere. Benedicat Deus Amen. ${ }^{1}$

"Sunday. April 22. 1677. about I I at night my daughter Lechmere was delivered of a foñe at my houfe at Hanley. hee was named Edmund, according to $y^{c}$ name of his father, great grandfather, and grandfathers Grandfather. Benedicat Deus Amen.

"Aug. or Sept. I677, I built the new pigeon houfe of brick.

" This winter $1677, \mathrm{I}$ inclofed $\mathrm{y}^{\mathrm{e}}$ colepit clofe in Northfield $\mathrm{w}^{\text {th }}$ a ditch $\&$ quickfet hedge.

"Tuefday. 9 Jul. I678. my daughter Ifabella was married to $\mathrm{M}^{\mathrm{r}}$ Richard Barneby of Brockhampton co $\tilde{m}$ Heref. Benedicat Deus Amen. ${ }^{2}$

"Sunday Morning Jul. 21, 1678. about one of $y^{e}$ clock in $y^{\mathrm{e}}$ morning my daughter Lechmere was delivered of a foñe at my houfe at Hanley. hee was named William. ${ }^{3}$ Benedicat Deus Amen.

1 Afterwards Lord Lechmere.

2 The P. R. of Hanley fays July 14, 1678.

${ }^{3}$ He died, unmarried, Sept. 26, 1725. 


\section{Houfe of Lechmere.}

"About ten at night, I I Nov. I679. my daughter Lechmere was delivered of a daughter at my houfe at Hanley. fhee was named Lucy (her Mothers name). Benedicat Deus Amen.'

“April. 1680. I built $y^{e}$ new round pigeon houfe. timber $\&$ workmanthip coit 16 .

" December 2 I, I680, my daughter Lechmere was delivered of a daughter at my houfe at Hanley named Penelope. She married William Scudamore Efq. of Kentchurch coũ Hereford. ${ }^{2}$

"In the yeare I 68 I, I built y new Malt-houfe \& brew-houfe. this yeare I fold the Mannor of Middleton in $y^{e}$ pirh of Bitterly in Shrophire and hortly after pchafed $y^{e}$ Mannor fladbury in Worcthire.

"June I 8th 1683. my daughter Lechmere was delivered of a foñe named Thomas. Benedicat Deus Amen. ${ }^{3}$

"I fold $y^{e}$ Mann $^{r}$ of Fladbury to $y^{e}$ Earle of Plymouth.

" 15, January 1683. I pchafed $y^{e}$ Mannor of Holdfaft.

" 3. Sept. i 686. I pchafed of Thomas Hornyold Efq. \& Rob $^{t}$ Hornyold his fone the Reverfion of $y^{e} 2$ a acres in Weit-

1 Added in a later hand:- "Shee married Henry Biggs Efq": of Benthall in the County of Salop: 8. June 1699. She died 26, June 1758."

2 This entry is in a later hand:- "She was married 20 Nov: 1701. and died in $1737 . "$

3 " $\mathrm{M}^{\mathrm{r}}$ Thos Lechmere died at Bofton in New England, the $4^{\text {th }}$ day of June 1765. He was Surveyor General of the King's Cuftoms for the Northern diftrict of America, and anceftor of the American branch of the family, ftill, I believe, exilting. There is a piece of land in Hanley called NEW ENGLAND, planted with oaks, the feeds of which were fent from America by Thomas Lechmere in January, 1733-4. He married Anne Winthrop." 


\section{Hanley and the}

more expectant upõ the death of John Surman \& one John Balliger.

" Oct. 6. i686. This day at $y^{e}$ generall quarter Seffions of $\mathrm{y}^{\mathrm{e}}$ peace held before the right hõble the Earle of Plymouth Lord Lieutñt of $\mathrm{y}^{\mathrm{e}}$ county of Worc ${ }^{\mathrm{r}} \mathrm{S}^{\mathrm{r}}$ Thomas Street knight one of his Mãties Juftices of $y^{e}$ Court of Comon Pleas, $S^{r}$ Francis Ruffell Bart: $\mathrm{S}^{\mathrm{r}}$ Francis Rous Baronet, $\mathrm{S}^{r}$ Rowland Barkley $\mathrm{K}^{\mathrm{nt}} \mathrm{S}^{\mathrm{r}}$ Thomas Haflewood $\mathrm{K}^{\mathrm{nt}}$ Samuel Sandys $\mathrm{W}^{\mathrm{m}}$ Bromley Henry Jeffreys Henry Townfende Efq ${ }^{\text {rs }}$ \& other Juftices was exhibited by $\mathrm{S}^{\mathrm{r}}$ Edward Dingley my kinfman whõ I had raifed out of $y^{e}$ dirt frõ a poore añuity of $25^{1} \mathrm{p}$ añ during his life $\&$ that upõ a defective title, a moft malitious accufation againft my fone tending to his utter ruine but by the good hand of Gods providence upon us (of which I have had frequent experience $\&$ of $\mathrm{w}^{\text {ch }}$ may neyther I nor my pofterity bee ever forgetful) and by the Juftice of the Court and the apparent malice of the informer $\mathrm{W}^{\mathrm{m}}$ R. \& the pfecutor $\mathrm{S}^{\mathrm{r}} \mathrm{E}$. D. $\mathrm{y}^{\mathrm{e}}$ defigne was difappointed $\&$ my fone difcharged to the thame of the moft ungratefull wretch $\mathrm{S}^{\mathrm{r}} \mathrm{Edw}$. D. if any thame bee in him. Laus Deo in eternum.

" January $y^{\text {e }} 25^{\text {th }}$ I 686 about nine at night my daughter Lechmere was delivered of a foñe named Richard. ${ }^{1}$ Benedicat Deus. ${ }^{2}$

1 Richard Lechmere was the anceftor of the Lechmeres of Steeple Afton in Oxfordhire; he married Elizabeth Corficld, widow of Thomas Swift, and died 28 January, 1774 .

${ }^{2}$ Here fome details as to fmall purchafes in Hanley are omitted. 


\section{Houje of Lechmere.}

"Friday. 25. April. I689. I $\mathrm{rec}^{\mathrm{d}}$ his $\mathrm{Ma}^{\text {tyes }}$ writ under $\mathrm{y}^{\mathrm{e}}$ great Seale of England comanding mee to prepare myfelf to take $\mathrm{y}^{\mathrm{e}}$ tate and degree of a Sergeant at Law a die pafche in unum mensü. Tefte apud Weftm. I I Apr. Año Regni ñri primo.

"May. I. 1689. I appeared in Chancery upon this Writ \& at $\mathrm{y}^{\mathrm{e}}$ barr of $\mathrm{y}^{\mathrm{t}}$ Courte I tooke $\mathrm{y}^{\mathrm{e}}$ oath of a Sergeant at law. $\mathrm{S}^{\mathrm{r}}$ Henry Pollexfen (the Kings Attorney) was firft fworn, \& I next, \& then $y^{\mathrm{e}}$ reft according to theyr antiquity. $\mathrm{y}^{\mathrm{e}}$ oath was read to us feverally by $\mathrm{M}^{\mathrm{r}}$. Barker Clerke of $\mathrm{y}^{\mathrm{e}}$ Crowne in Chancery. Noe other oath was adminiftered to any of us.

"Wenfday. 8. May. I recđ my patent to bee a Baron of the Excheq $\tilde{r}$, it was delivered mee at $y^{e}$ Lord Comiffioner Maynards houfe in Lincolne's Inne fields. I then tooke $y^{e}$ oath of a Baron, read to mee by $M^{r}$ Hall of the kings remembrancers office. I then alfo tooke $y^{e}$ oaths $\mathrm{p}^{\mathrm{r}}$ fcribed by $\mathrm{y}^{\mathbf{e}}$ Act of I. Gulielmi et M. intituled an Act for abrogatinge $y^{e}$ oaths of fupremacy \& allegiance \& appointing other oaths.

"May. 24. I recđ theyr $\mathrm{Ma}^{\text {tyes }}$ Writ for attendance in $\mathrm{y}^{\mathrm{e}}$ houfe of peeres. \& accordingly I attended that day. $\mathrm{w}^{\mathrm{ch}}$ day his $\mathrm{Ma}^{\text {ty }}$ in his robes of ftate and crown on his head came into $\mathrm{y}^{\mathrm{e}}$ houfe of peeres $\&$ taking his place under $\mathrm{y}^{\mathrm{e}}$ cloath of ftate $\mathrm{y}^{\mathrm{e}}$ com̃ons attending wh theyr Speaker at $\mathrm{y}^{\mathrm{e}}$ barr, his Mã gave his Royall affent to 3 bills, 1 . for indulgence to Diffenting $p^{\text {teftants, }} \mathrm{y}^{\mathrm{e}}$ fecond for reverfing $\mathrm{y}^{\mathrm{e}}$ attainder of the Lady Linle beheaded by Jeffreys in $y^{\mathrm{e}}$ Weft, \& the third for felling fome houfes at Piccadilly formerly belonging to $\mathrm{M}^{\mathrm{r}} \mathrm{H}$. Coventry. "Tuefday. 3. June. I690. my deare wife dyed at her lodg- 


\section{Hanley and the}

ings in Devonfhire Square London, being then of $y^{e}$ age of 73 yeares. Shee was buried in $y^{e}$ church of $S^{t}$ Anne Alderfgate according to her owne defire, it being the place of her birth, $\&$ in w $^{\text {ch }}$ Church thee was baptized. ${ }^{1}$

“I. May. 1693. My 2 grandfones Anthony \& Nicolas were admitted into $\mathrm{y}^{\mathrm{e}}$ middle Temple. Benedicat Deus."

[The above is the laft entry in the autograph of $\mathrm{S}^{r}$ Nicholas Lechmere; what follows is in that of his daughter in law, Mrs. Lucy Lechmere, who for a hort time appears to have continued the Journal.]

"Thurfday night neare Eleven of $y^{e}$ clock, Apr: $30^{\text {th }} 1701$, dyed my worthy good ffather in law $\mathrm{S}^{r}$ Nicholas Lechmere, at his houfe in Hanly Caftle, and was buryed in $\mathrm{y}^{\mathrm{e}}$ outter Chancell of $\mathrm{y}^{\mathrm{e}} \mathrm{s}^{\mathrm{d}}$ church on $\mathrm{y}^{\mathrm{e}} 3^{\mathrm{d}}$ of May at twelve of $\mathrm{y}^{\mathrm{e}}$ clock at $\mathrm{n}^{\mathrm{t}} \mathrm{w}^{\text {th }}$ out a coffin; according to his own direction; he was then in $y^{\mathbf{e}} 88^{\text {th }}$ yeare of his age. he was a man of great piety $\&$ learning $\&$ kind to all."

Although it cannot be denied that Sir Nicholas Lechmere, or Judge Lechmere, as he is now generally remembered, was fomething of a time-ferver, and was not always loyal to the Crown, yet he was not only a great and eloquent lawyer, but alfo an amiable and kind-hearted man; nor thould his defcendants ever forget the obligations they owe him, who was the

I Sir Nicholas Lechmere had alfo two other grand-daughters whom he has omitted to mention, Rachel and Margaret; the firft married Welwyn Shepherd; the fecond, in 1721 , Henry Rider, Clerk; Rachel was baptized Oct. 21, 1684; Margaret was born about October, 1690. 


\section{Houfe of Lechmere.}

Reftorer of the fortunes of the family, as well as the careful chronicler of the annals of former times. An early proof of his labours in this direction is contained in the following letter, written from the Middle Temple : "To the right wor" my honoured friend Thomas Habington Efq at Hinlip." This muft have been before I647, when Mr. Habington, the Worcefterhire antiquary, died. He had been confined to that county, as is well known, in confequence of his participation in the Gunpowder Plot, and amufed himfelf by making collections for the "Hiftory of Worcefterfhire," now preferved in the library of the Society of Antiquaries.

"Noble $\mathrm{S}^{\mathrm{r}}$. The refpect you did mee in the letter you were pleafed to fend mee, and the other favours I have formerly receaved from you, commaunds my beft fervice to you and yours; and for your kinfwoman the bearer I thall readily give her what affiftance I am able, but fince thee deliver'd your lree, I never heard of her, foe that to the merits of her caufe I can yet fay litle.

"What you have written concerning our family is I conceave according to truth, but a match or two $\mathrm{w}^{\text {th }}$ the daughters and coheires of Whitmore and de Rupe, for $\mathrm{w}^{\mathrm{ch}}$ our evidences are plaine, it feemes you have not been hitherto informed of : all the alteration I defire is onely this, that you would bee plear'd to remember us in the forme here underwritten, a forme agreeing in fubftance $w^{\text {th }}$ your owne, but more expreffely alliancing us to fome noble houfes, $w^{\text {th }}$ a litle taking notice of our armes and the pleafantneffe of our homeftall. 


\section{Hanley and the}

\section{LECHMERE.}

"Eaftward in this parifh towards the river of Severne is the pleafant feat of the Lechmeres, a family very auncient there, they came in $\mathrm{w}^{\text {th }}$ the Conqueft, as appeareth in an authentick record in fflaunders, the copy whereoff I have inferted in this booke, ${ }^{1}$ and by theyr continuaunce here to this day have given theyr name to Lechmeres place in Hanley; they have match'd with the daughters and coheires of Whitmore and de Rupe or Rock, as likewife $\mathrm{w}^{\text {th }}$ ffrere, defcending by marriages from fundry knights, and likewife from Dineley, extracted from very many noble houfes, as Nevill lords Abergavenny, Windfor $\&$ others; and laft of all $\mathrm{w}^{\text {th }}$ a daughter of $\mathrm{S}^{\mathrm{r}}$ Nicholas Overbury knight : theyr armes I am inform'd are Gules a fefle or, in chief two pelicans of the fecond. Thefe few lines I write, as well to manifeft a trueth, as allfo in requitall of $\mathrm{M}^{\mathrm{r}}$ Edmund Lechmeres fr ${ }^{\mathrm{al}}$ friendfhip to mee in my greateft and moft daungerous troubles. ${ }^{2}$

"And now Sir tis time to crave your pardon for the great trouble I caft upon you in reading this lire, $w^{\text {ch }}$ is wholly imploy'd about myfelf. I fhall wait for an opportunity to expreffe my thanks to you, and foe for the prefent I take my leave and reft $\mathrm{S}^{\mathrm{r}}$ your moft humble Servant, Nic: Lechmere.-Mid Temple." 3

1 There is no fuch copy in the original MS.

2 This refers, no doubt, to the Gunpowder Plot.

3 Sealed with the fingle arms of Lechmere. 


\section{Houfe of Lechmere.}

Of Edmund Lechmere, Efquire, the eldeft fon of Sir Nicholas, who furvived his father but two years, his widow (Lucy Hungerford) has left us the following agreeable character, which the wrote at the time of his deceafe in the family chronicle :-

"Sunday Morning neare 8 of $y^{\mathrm{e}}$ clock Jan: $6^{\text {th }} 1703$ at $y^{\mathrm{e}}$ houfe of Alderman Gibbs in Bath, dyed my deare \& loveing hufband $E \mathrm{dm}_{\mathrm{d}}^{\mathrm{d}}$ Lechmere $\mathrm{Eqq}$ i in the 55 yeare of his age, upon $y^{e} 12$ day of $y^{e}$ fame month he was brought to his own houfe at Hanly; and from thence caryed to $y^{\mathrm{e}} f_{\text {: }}^{\mathrm{d}}$ Parifh Church where about 9 a clock at $n_{:}^{t}$ he was buryed neare to his ffa: $\mathrm{S}^{\mathrm{r}} \mathrm{N}$ : L: he was a moft kind \& Loving hurband, an Indulgent ffather, a moft Admirable Majeftrate, never wanting to his neighbours but allways redy to Affift them in whatever their occafions required, and perticularly $y^{e}$ poorer fort, who, I have often hard him fay he look't upon to be his chiefe concern to take care of; not only in his advice; but his pockett was allways oppen to relieve thofe he thõt wanted. he was a pyous good Xian, \& I befeech $y^{\mathrm{e}}$ Lord to grant $\mathrm{y}^{\mathrm{e}}$ Children $\left(\mathrm{w}^{\mathrm{ch}}\right.$ are ten, 6 fons 4 daughters) he has left behind him may endeuore to tredd in his fteps, \& I pray God to blefs them."

The laft entry in the Judge's Book was alfo written by Mrs. Lucy Lechmere, whofe orthography is fomewhat faulty; it relates to the great ftorm of 1703 , and is as follows:-

"Nov: $26^{\text {th }} 1703$ upon this morning at $\mathrm{I}$ of the clock \& till after five was the moft dredfulleft ftorm of Wynd ( $\&$ by 


\section{Hanley and the}

many thõt an earthquake) that ever was hard in England, in all parts $y^{e}$ people fuffer'd greatly, both in their houfing \& trees, but more at fea by lofs of many men of Warr \& Marchants thips; \& feverall thoufand men loft their lives."

Madam Lucy Lechmere, widow, was buried November

Lechmere, impaling, argent, a fefs engrailed, between tbree cinquefoils fable, all within $a$ border of the laft. Foley.

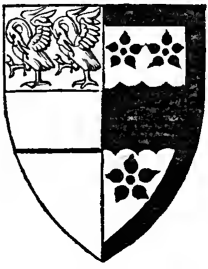
1 7, 1729. ${ }^{1}$ Anthony, eldeft fon of Edmund Lechmere and Lucy Hungerford, married Anne daughter of Thomas Foley, of Stoke Edith, in the county of Hereford, Efq., by whom he had iffue two children, Edmund and Lucy. ${ }^{2}$ He died at the age of fortyfix, and is buried at Hanley, where a Latin infcription records his many virtues. ${ }^{3}$ His lofs is alfo recorded on the cover of the old Regifter of the parifh of Severn Stoke in Worcefterfhire, in the following words :-

"Honeft inienious Anthony Lechmere $\mathrm{Efq}^{\mathrm{r}}$ was well at his Church at Hanley Caftle, Sunday February $7^{\text {th }} 17 \frac{1}{2} \frac{9}{0}$ and fang Pfalm, on $y^{e}$ morrow ffeb : 8, at dinner time he dyed of an apoplexy, and was buryed privately at 7 at night Thurfday Feb : I I, I $7 \frac{1}{2} \frac{9}{0}$ to $y^{\mathrm{e}}$ great lofs of all honeft people in $y^{\mathrm{e}}$ Country."

Nicholas, fecond fon of Edmund Lechmere and Lucy Hun-

1 P. R. Hanley-Cafte. The pulpit cloth ftill in ufe in Hanley Church was given by Mrs. Lucy Lechmere; it is of fine crimfon velvet, and ornamented with her arms, embroidered with gold and colours.

2 Lucy Lechmere married Rowland Berkeley of Cotheridge, Efquire.

3 See p. 69. 


\section{House of Lechmere.}

gerford, was, like his brother Anthony, bred to the law, and greatly diftinguifhed himfelf as an Advocate. His career was, however, in danger of being cut off in January, 1693, when he nearly died of the fmall-pox, being at that time nineteen years of age. He was attended by Dr. Morton, and "the excellent $\mathrm{D}^{\mathrm{r}}$ Cole." He had the advantage of having adminiftered to him "compound Powder of Crabs Claws \& Eyes," as well as "The afbes or powder of Toads," "and the refult was, whether from thefe remedies or the ftrength of his conftitution, all that could be wifhed.

In the reign of George I., Nicholas Lechmere rofe rapidly to diftinction. In 1717, March 14, he was appointed Solicitor-General, and the fame year, June I2, Chancellor of the Duchy of Lancafter for life. He was raifed to the peerage as Baron Lechmere of Everham, Auguft 25, I721. He married, in 1719 , the Lady Elizabeth Howard, eldeft of the three daughters of Charles, Earl of Carlifle, and died, without iffue, June 18, 1727. Lord Lechmere, though an excellent lawyer, was violent and overbearing. He was one of the managers againt

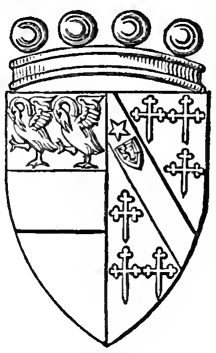
Dr.Sacheverell, and moved the impeachment againft Lord Der-

1 From the original receipt penes Sir E. L., Bart.

2 She remarried Sir Thomas Robinfon, of Rokeby, in the County of York, Bart. She died in 1739. 


\section{Hanley and the}

wentwater, one of the (fo-called) rebel lords. For his indecent intrufions into the King's Clofet fee Coxe's "Hiftory of Sir Robert Walpole" (i. p. 264); and Swift's works for the ballad called "Duke upon Duke," a ludicrous account of a quarrel between Lord Lechmere and Sir John Guife, faid to be written by Gay. His portrait is in the great gallery at Northwick, three-quarters length, dreffed in purple, with a very large dark wig. Lord Lechmere died at Camden Houfe, of apoplexy, while at table, and was buried at Hanley, where a nab is infcribed to his memory. ${ }^{1}$

Edmund, third fon of Edmund Lechmere and Lucy Hungerford, deferves alfo fome notice here. His fervices to his country will be beft underftood from the following infcription from a monument in St. Andrew's Church, Plymouth: ${ }^{2}$ "Near this place is interr'd the body of CAPT EDMUND LECHMERE, formerly Commander of Her Majefty's Ship Lynn, and late of the Lyme Frigat of 32 guns : on Boord of which he departed this life $y^{e}$ fixteenth of January, 1703, of the wounds he received the fifteenth in an Engagement with a French Privateer, of 46 guns; from whom he protected a large fleet of Merchant fhips, all into fafety, and then bravely

I “ 1727. The $\mathrm{R}^{\mathrm{t}} \mathrm{Hon}^{\text {ble }}$ Nicholas $\mathrm{L}^{\mathrm{d}}$ Lechmere was buried July $\mathbf{2}^{\mathrm{d}}$ from Campden Houfe in Kenfington. $\operatorname{Rec}^{d} y^{e}$ forfeiture $2^{11} 10^{8}$ for $y^{e}$ ufe of $y^{e}$ poor for his being buried in a coffin covered with velvet."P. R. Hanley-Caftle.

2 This monument fell down about the year 1843 , but has been fince that time well reftored by the parochial authorities. 


\section{Houfe of Lechmere.}

gave the Enemy battle, and forced Him to bear away with very much damage. He was in the beginning of the Action, wounded in both knees, and afterwards received a mufquet thot thro' his Body, yet by neither difcouraged from profecuting $\mathrm{y}^{\mathrm{m}}$ with $\mathrm{y}^{\mathrm{e}}$ utmoft vigour. Thus fell this brave man, who in his early years had as well by the conftancy of his good difcipline and prudent conduct as by his intrepid gallantry in this and feveral other actions, rendered himfelf famous in many parts of the world, fervicable to his Queen and Country; highly efteem'd by the Commanders of the Fleet; entirely belov'd by the Seamen; and univerfally lamented by all that knew him. He was third fon of Edmund Lechmere of Hanley Caftle in the County of Worcefter Efq by Lucy his wife, Daughter of Anthony Hungerford, of Farleigh Caftle in the County of Somerfet Efq. Anno Ætatis 27." ${ }^{1}$

Edmund, only fon of Anthony Lechmere and Anne Foley, who was born April 4, and baptized at Hanley, April 13, 17 10," married early in life (Oct. I 2, I 732) Elizabeth, daughter and heir of Sir Blundel Charlton, of Ludford, in the County of Hereford, Baronet. Their iffue, taken from a Family

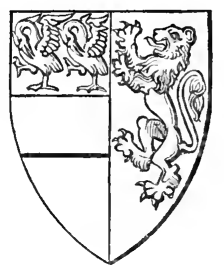
Bible now at The Rhyd, ${ }^{3}$ was as follows :-

"Nicholas Lechmere, fon of Edmund Lechmere Efq and

1 There is a fea-cheft at The Rhyd which belonged to Captain Edmund Lechmere.

2 P. R. Hanley.

3 Barker's Folio Bible, 1602.

Lechmere, impaling, or a lion rampant, gules. Charlton. 


\section{Hanley and the}

Elizabeth his wife, was born on Tuefday the $18^{\text {th }}$ day of December I 733, between $7 \& 8$ o'clock in the even, at the houfe of $\mathrm{M}^{\mathrm{r}}$ John Hunt, Attorney at Law, in the parifh of $\mathrm{S}^{\mathrm{t}}$ Swithin in the City of Worcefter, and Baptized the $8^{\text {th }}$ day of January following, by the Rev : $M^{\mathrm{r}}$ Dennies, vic : of Swithin afors $^{d}$ : His Sponfors were, The Hon ${ }^{\text {ble }}$ Tho: Foley $\mathrm{Efq}^{\mathrm{r}}$ Audir of the Imprefs, \& Paul Foley Efq ${ }^{r}$ of Newport in the County of Hereford, and Lady Charlton of Ludford.

" Edmund, fon of Edmund Lechmere Efq ${ }^{\mathrm{r}}$ : and Elizabeth his wife, was born at Hanley-Caftle, on Tuefday the ${ }^{\text {th }}$ day of September 1 747, between $2 \& 3$ o'clock in the afternoon, and baptized in the parifh Church of Hanley afores ${ }^{d}$ by the $\operatorname{Rev}^{\mathrm{d}} \mathrm{M}^{\mathrm{r}}$ Brooke upon Wednefday the $7^{\text {th }}$ day of October following. His Godfathers were Tho ${ }^{\mathrm{s}}$ Foley Efq of StokeEdith in the County of Hereford, and Richard Lechmere $\mathrm{Efq} \mathrm{q}^{\mathrm{r}}$ of the City of Worc ${ }^{\mathrm{r}}$, both in perfon, \& $\mathrm{M}^{\mathrm{rs}}$ Lechmere of London, Godmother, by her proxy $\mathrm{M}^{\mathrm{rs}}$ Em̃a Charlton.

" $\mathrm{M}^{\mathrm{rs}}$ Elizabeth Lechmere died upon Monday the $13^{\text {th }}$ day of September 1 762, about 3 o'clock in the afternoon, at her Lodgings upon Clifton Hill, near the Hott Well Briftol, and was buryed at Hanley Caftle, on Tuefday the $2 \mathrm{I}$ of September following."

On the $4^{\text {th }}$ of June $1765, \mathrm{M}^{\mathrm{r}}$ Lechmere remarried Elizabeth daughter of the Rev. John Whitmore, Vicar of Lechlade in Gloucefterfhire. They had iffue an only fon, born November 2, 1766 , "being Sunday Morning, between $3 \& 4$ o'clock," baptized the fame day at Hanley, and chriftened Anthony. 


\section{Houfe of Lechmere.}

In his younger days in 1734 , and again in $1741, \mathrm{M}^{\mathrm{r}}$ Lechmere reprefented his native County in Parliament, and was throughout his life of much confideration in Worcefterfhire. His grandfon, the late Sir Edmund Lechmere, remembered him well, and has preferved many curious particulars of his latter days, and the patriarchal ftate in which he lived. He draws a pleafant picture of this fine old Englifh gentleman,

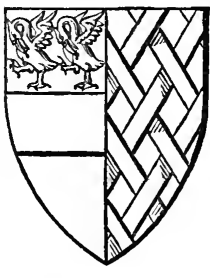
furrounded by his family and tenants, fomewhat choleric in temper, and ftrict in the difcipline which he kept up in his houfehold : but withall a liberal and humane mafter, his dependents growing grey in his fervice. His fecond wife was a moft admirable woman, "whofe fimplicity and kindnefs attracted the refpect of all who approached her. Her religion was fincere and fervent, without pretence; her charity unoftentatious and univerfal, extending not only to almfgiving but to covering the failings of others."

Mr. Lechmere furvived till his ninety-fifth year, departing this life in April, I 805. He was buried at Hanley on the 5 th of April, I 805. ${ }^{1}$ Upon his deceafe the ancient houfe of Lechmere was divided; the reprefentation of the family, indeed, and the poffeffion of Hanley or Severn-End, devolved upon his eldert fon, Nicholas, who had taken his mother's name of Charlton in addition to his own, and was generally known

I P. R. Hanley-Caftle. 


\begin{tabular}{|c|c|}
\hline 60 & Hanley and the \\
\hline $\begin{array}{l}\text { Lechmere, im- } \\
\text { paling, argent, } \\
\text { three bears' } \\
\text { heads erafed } \\
\text { fable, muzzled, } \\
\text { gules. } \\
\text { Berwick. }\end{array}$ & 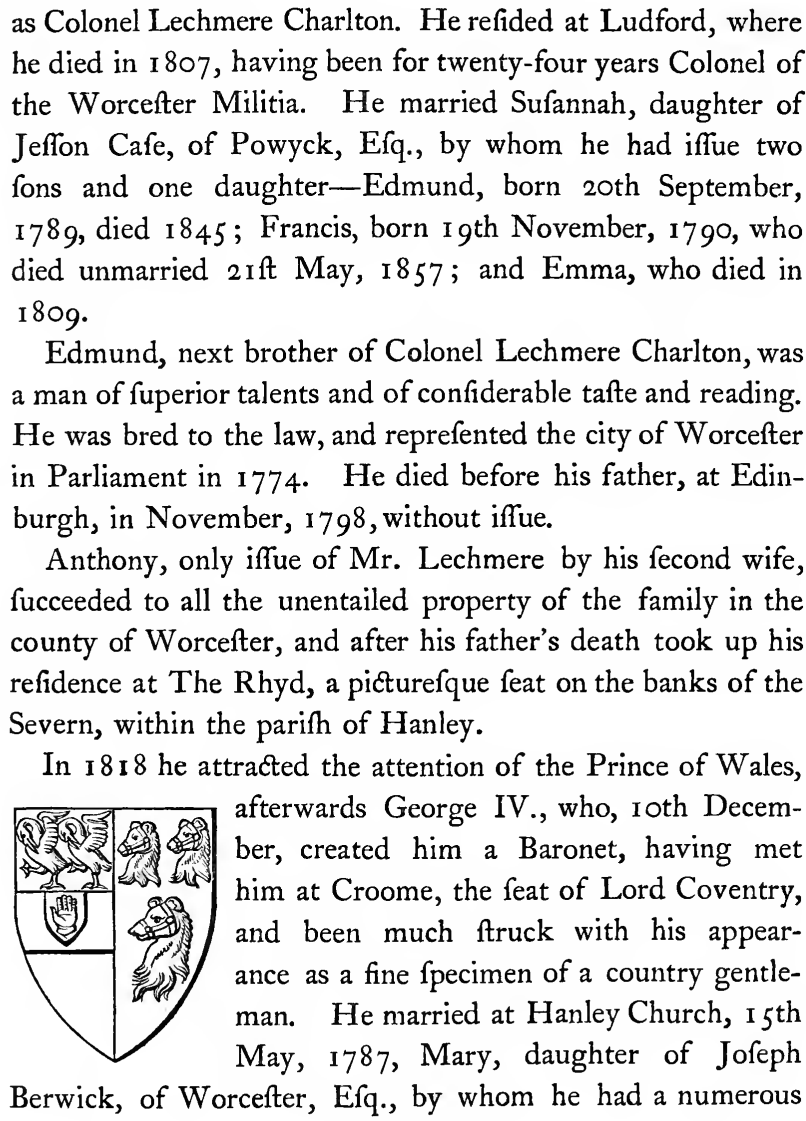 \\
\hline
\end{tabular}




\section{Houfe of Lechmere.}

iffue. She died 3 rd of December, 1820 , and was buried on the I I th of that month at Hanley-Caftle. Sir Anthony Lechmere remarried, 8th September, I823, Elianor, daughter of $\mathrm{Mr}$. Bayley Villiers, of Gloucefter. She died 20th Aug., I 837 , having had iffue one fon, William Henry, born I 5 th O\&t., I 825 ; he died 2nd March, I 857 , and was buried at Hanley. Sir Anthony died on the $25^{\text {th }}$ of March, 1849 , and was alfo there interred.

Mr. Edmund Lechmere Charlton, the eldeft fon of Colonel Lechmere Charlton, died unmarried.

In the year I 830 he fold, to a Mr. Paget, the Severn-End eftate, the venerable inheritance of his anceftors, which was after the lapfe of twenty-two years repurchafed by the late Sir Edmund Hungerford Lechmere, on the 2nd of November, I 852 .

The children of Sir Anthony Lechmere by his firt wife Mary were :-

I. Sarah, born 2 May, 1788 ; died I3 Feb., I864, and buried at Hanley.

2. Eliza-Anne, born I I Aug., I789; married I4 Feb., 1847, Samuel Wall, of Worthy Park, Hants, Efq.; the died 26 Dec., I 875, and is buried at Hanley.

3. Frances, born I4 March, I79I; died 29 Jan., I847, buried at Hanley.

4. Edmund-Hungerford, born 25 May, 1792.

5. Mary-Foley, born 16 Aug., 1799; died 24 Feb., 1803.

6. Anthony-Berwick, born 28 Sept., I802; Vicar of 
62

Lechmere, impaling, azure tbree mullets within a double treflure of Scotland, argent a martlet or. Murray.

\section{Hanley and the}

Hanley-Caftle, Honorary Canon of Worcefter Cathedral, and Rural Dean ; married, I I Oct., I 840, Emily Mary, daughter of Sir Harry Darell, Bart. She died 20 Aug., I 857, f. p. The Rev. Mr. Lechmere died 8 Oct., I 878.

7. Jemima-Ifabella, born 30 July, 1804 .

8. Georgiana-Felicia, born i I June, i 806 .

9. Emma-Catherine, born 20 May, 1809 ; married, 9 Aug., 1 852, William Candler, Com. R.N. He died 8 April, 1865 .

Sir Edmund Hungerford Lechmere, 2nd Baronet, married, 22 June, I8 I g, the Hon. Maria Clara, Maid of Honour to

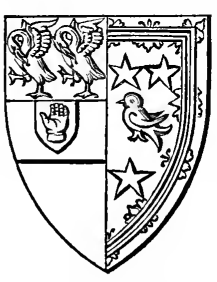

Queen Charlotte, and daughter of the Hon. David Murray, of the Elibank family. She died 29 Jan., 1865. Sir Edmund died 2 April, 1 856; both were buried at Hanley. They had iffue :-

I. Mary-Clara-Elizabeth, born 22 Oct., I 823; married, 4 Aug., I 842, Evelyn Philip Shirley, of Ettington, in the County of Warwick, and Lough Fea, in the County of Monaghan, Efquire.

2. Edmund-Anthony-Harley, born 8 Dec., 1826 , 3rd and prefent Baronet; married, 30 Sept., I 858 , Louifa Rofamond Katharine, only furviving child of John Haigh, of Whitwell Hall, Yorkfhire, Efq.

3. Louifa-Augufta, born 9 Feb., I 829 ; married, 17 July, I 858, Monfieur Lambert Louis D'Arras, of St. Valerie, in Picardy. 



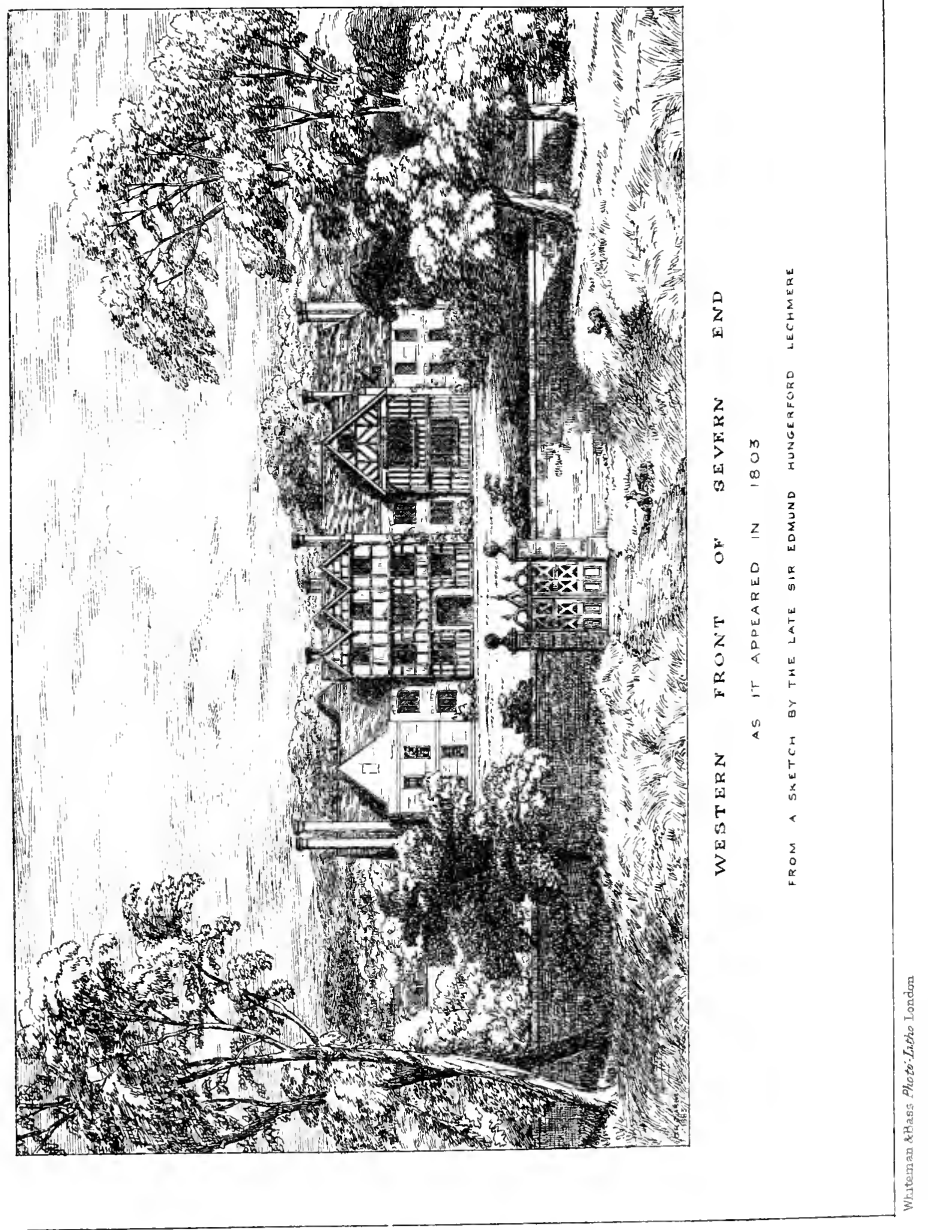




\section{House of Lechmere.}

The children of Sir E. A. H. Lechmere are :-

I. Alice-Mary, born 9 March, and died 3 Dec., I 862. Buried at Hanley.

2. Reginald-Hungerford, born I4 Jan., died I March, 1864.

3. Edmund-Arthur, born 2i Sept., I 865.

4. Anthony-Hungerford, born I 5 July, I 868 .

5. Jofcelyne-Alban, born i 9 Dec., I 87 I.

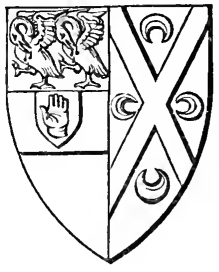

6. Katharine-Mary, born 28 Feb., i 875.

7. Nicholas-George-Berwick, born 20 Sept., I 88 I.

Of the Ancient Seat of the Lechmeres, now Called Severn End.

The defcription which follows of this old houfe is principally from the pen of the late Sir Edmund Lechmere; it was written about the year I 854 .

The ancient feat of the Lechmeres ftands upon a bank overhanging flat and fpacious meadows on its eaftern front, through which the Severn, almoft concealed by the marly fhores, flows towards Upton, whofe church is feen to the S.E. On the oppofite fhores are the woods of a part of Croome domain, encircling the pleafant retreat called Severn Bank, belonging to Lord Coventry. A few old ftag-headed oaks, the venerable lords of the foil, diverfify the green expanfe. The fituation did not efcape the quick eye of

Lechmere, impaling, azure, a faltive between in chief a crefcent reverfed, in dexter $\mathrm{fe} / \mathrm{s}$ a decrefcent, in finifter $f e / s$ an increfcent, and in bafe a crefcent argent. Haigh. 


\section{Hanley and the}

Horace Walpole as he travelled between Worcefter and Upton in September, 1753. He notes Mr. Lechmere's houfe, and playfully adds that " he had given ftrict charge to a troop of willows never to let him fee the river. To his right hand extends the fineft meadow covered with cattle that ever you faw; at the end of it is the Town of Upton, with a church half ruined, and a bridge of fix arches, which I believe with little trouble he might fee from his garden." 1

The centre of the houfe is chiefly in the black and white timber and plafter ftyle, with gables ornamented with wooden carvings and emboffed leaden fpouts. The delicate carving of the brackets carrying the overhanging foffits to each floor, and the very curious caft-lead crefting to the gables deferves attention. This part of the houfe was probably built about 1580. In the centre is a maffive door ftudded with iron knobs, opening to a paffage, on the left of which are the fervants' hall and domeftic offices; on the right, a fmall panelled hall conducting to the beft apartments. A correfponding door at the end of the paffage opens to a formal garden. Some fragments of heads near the entrance, and fome appearances of a ftone foundation, indicate remains of an earlier period. The wings of brick, having each three gables on which are fhields bearing the date [1673], fhut in on either fide a formal court, formed by an iron palifade, in the centre of which is a florid iron gate, the pillars on either fide fur-

${ }^{1}$ Horace Walpole to Bentley, Sept., 1753. 


\section{House of Lechmere.}

mounted by a lion and a dog carved in ftone. The weft fide of the houfe is lefs regular, and chiefly prefents a mafs of unequal gables of black and white, more or lefs ornamented with carved mouldings. Here was the principal flower-garden, laid out in formal parterres, fome of them edged with box, and laid out in patterns of curious defign. This garden was thut in by walls covered with grapes, plums, or cherries, having four doors, one at each corner; one opening to a chicken court, the others for gardens appointed for fruits and other produce, according to their afpects. In the centre of the wall, oppofite to the houfe door, was a lofty gate of maffive woodwork, conducting to a crefcent-hhaped avenue of elms, about three-quarters of a mile long, with a pathway underneath leading to the village of Hanley. ${ }^{1}$ Colonies of rooks had long found a refuge in the overhanging branches, which formed an arched canopy, refembling the long perfpective of a Gothic aifle. Here had once been a deer-park, difparked by Mr. Lechmere, the father of Sir Anthony, about the year I 790, and the deer fent to Ludford, the Charlton feat in Herefordfhire. The park was at that time divided into enclofures, and many of the trees removed. Sun-dials, raifed terraces approached by flights of fteps, thick hornbeam hedges, and here and there a fummer-houfe, befides the Judge's ftudy in the fouth-eaft angle, were the other characteriftics of thefe gardens. The Malvern Hills hut in the profpect. A vaft

1 Planted by the Judge in 1641 and 1650 . 


\section{Hanley and the}

range of barns, granaries, ftables, and brew-houfes-indicative of large confumption and of prevailing hofpitality-occupied an ample fpace clofe to the houfe on the north fide, and from thence was a road leading to other nurferies, or gardens and orchards, celebrated for the variety and excellence of the apples; and to barns and ftalls fitted for the reception of the various kinds of grain, and for the progreffive nurture and fattening of the cattle in their feveral ftages. One, diftinguifhed as the fattening barn, prepared many a victim for the Smithfield market.

The old houfe had few ftriking features within, nor were its arrangements convenient, or fuited to modern tafte. The entrance hall, it has been already ftated, was not of large fize, and wainfcoted with oak. In the windows were the following eight coats of arms in well-defigned fhields, no doubt placed there by $\mathrm{S}^{\mathrm{r}}$ Nicholas Lechmere :-

I. Lechmere, impaling, vert fretty or. Whitmore.

2. Lechmere, impaling, azure a cheoron between three dolphins embowed argent. Frere.

3. Lechmere, impaling, argent, a cbevron engrailed, between tbree chefs rooks, Sable. Rock.

4. Lechmere, impaling, argent a fe/s Sable, in chief a mullet of the Second, between two ogreffes. Dyneley.

5. Lechmere, impaling, fable, tbree mullets in bend argent, cotifed of the fecond. Overbury.

6. Lechmere, impaling, or, a fe/s dancette between three cro/s croflets fitché gules. Sandys. 


\section{Houfe of Lechmere.}

7. Lechmere, impaling, fable, two bars argent, in chief three plates. Hungerford.

8. Lechmere, impaling, argent, two bends indented, gules and vert. Ruyhale.

This laft impalement is, I believe, the only exifting evidence of any match of the Lechmeres with the old and extinct family of Ruyhale, feated in the fourteenth century at a place of that name in Ripple.

In this hall was formerly a fine old oak table, now preferved in the dining-room at Madresfield Court. Hanging on the wall is a portrait of Edmund Lechmere, Efq., the great grandfather of the prefent Sir Edmund, riding a race at Newmarket. The traditional ftory is, that he had a dream, that (in the flang language of the turf) " he had been Sold," that is, that his jockey had been tampered with. He haftened to Newmarket on a fleet horfe which had formerly belonged to a highwayman, and arrived there juft in time to ride the race himfelf, which he won, and had this picture painted in commemoration of the fact.

The dining-room, adjoining the hall, is the largett room in the houfe. It is very low, with a heavy ceiling of ftucco. Over the ample fireplace in old times hung a portrait of George I. This room is panelled with oak, painted white. Here alfo were the following portraits, fome of which are ftill preferved at The Rhyd, the prefent and more modern feat of the family: Sir Nicholas Lechmere, the Judge, in his robes, a good portrait, marked, "anno dñi 1694, Etatis 81." Penelope Sandys, 


\section{Hanley and the}

wife of Sir Nicholas, a fmall whole-length in white fatin. Portrait of a young man with turned-down collar, suppofed to reprefent the Judge when young, by Vandyke (?). Edmund Lechmere, Efq., father of the Judge, in a brown drefs, with beard, half-length. $\mathrm{M}^{\text {rs }}$ Lucy Lechmere, daughter of Anthony Hungerford, Efq., arms in a lozenge, half-length. The above portraits are all at prefent in the dining-room at The Rhyd. The following are believed to be at Ludford: Anthony Lechmere, Efq., and his wife, Anne Foley, and two older portraits, marked, "His Honour Lechmere," and "Madame Lechmere," of the latter time of Elizabeth, and reprefenting probably Edmund Lechmere and Anne Dyneley his wife.

The drawing-room, a fmall room in the north wing, divided from the dining-room by a lobby and heavy open ftaircafe, was formerly hung with white emboffed leather, reprefenting the ftory of Meleager and Atalanta. The greater part of the building is occupied by ftaircafes and long paffages, and now and then a dark retreat or clofet, formed by the fuperincumbent angles of the roof. The late Sir Edmund Lechmere diftinctly remembered the old tapeftry with which fome of the rooms were hung, and the large patterns in flock paper with which others were ornamented, as well as the ancient bedfteads with maffive carved tefters and plumed canopies. On the ftaircafe near the lumber-room hung portraits of Lord Lechmere and his gallant brother Captain Edmund Lechmere, killed at fea. Thefe pictures are now at Steeple Afton in Oxfordfhire, the 


\section{House of Lechmere.}

prefent feat of Mr. Ogle, whofe mother was the heirefs of the Lechmeres of that place.

In the fouth-weft corner of the garden ftill remains the pleafant and commodious ftudy built by Judge Lechmere in the year 1661. A ftaircafe afcends from the garden, and in the window of the upper room is the following infcription under the family arms :-

"This ftudy was built by Sir Nicholas Lechmere, Knight, Baron of the Exchequer, anno 166r. Having become much dilapidated, it was completely reftored by his defcendant Sir Edm $^{d}$ A. H. Lechmere, Baronet, anno I 86I."

Inscriptions in the Church of Hanley-Castle and Churchyard to the Lechmere Family.

The church of Hanley-Caftle is a picturefque building in a beautiful fituation on the fouthern fide of the village, with a fine profpect of the Malvern Hills. The double nave is of the fourteenth century, with a doorway in the fouth wall of Norman work. There are two chancels, built in 1674 , of brick, with a heavy central tower of the fame material. The church was well reftored in the year $1857^{-8}$ by Sir Edmund A. H. Lechmere, in memory of his father.

The earlieft of the fepulchral infcriptions to any of the Lechmere family of which we have any account, is the following, preferved in Habington's "Survey of Worcefterhire," 


\section{Hanley and the}

now in the library of the Society of Antiquaries. There are at prefent no remains of this infcription :-

"In $y^{e}$ fouthe fyde of $y^{e}$ Church, lye under a ftone inlayd $w^{\text {th }}$ braffe $y^{e}$ refemblance of them whofe Infcription followethe ' Here lyeth buried under this ftone the body of Richard Lechmere Gentellman, who deceafed 23 Mart : I 568, leavinge behynd him Margery his Wyfe, ${ }^{1}$ of whome he had towe fonnes, Richard \& Edmund, and feaven daughters, ffrauncys, Joane, Elianor, Mary, ffrauncis, Mary, and Winefred, God fend them a joyfull refurrection." "There is added in a later hand, "a little of the brafs of the lady remains, all the reft gone."

The next in point of date ftill remains, though mutilated and mifnamed, in its original pofition. Habington's account is as follows :-

"In the northe wyndowe of $\mathrm{y}^{\mathrm{e}}$ pary he church, azure a bend barry, indented or and gules. Bracy of Warndon co: Wigorn : In $y^{e}$ north wall of this chauncell is made a Gentellwoman prayinge $\&$ over her head in a Lozeng azure 3 broad arrowes 2 E 1 . or, w $w^{\text {th }}$ a creffent for difference. Archer. Subfcribed thus :-

" Here lyethe $y^{e}$ body of Anne daughter of John Archer Gentellman ${ }^{2}$ and wyfe to Roger Lechmere of Fanhope (ats Favenhope,) in $y^{e}$ Coñty of Hereford gentelman, by whome

1 She was the daughter and co-heir of Thomas Rock, fee p. 9.

2 I conclude this to be Anne Savage, fee p. 9, note. 


\section{Houje of Lechmere.}

he had towe fonnes Thomas \& Roger, the departed this life ı Maii an : Do: 1614." (There is added in a later hand "gone.") The effigy, however, ftill remains as here reprefented, and underneath on a tablet of apparently the eighteenth century is the following mifleading infcription :- " Neare this Place Lyeth Interred the Body of $\mathrm{M}^{\mathrm{rs}}$ Winifred Lechmere, a Daughter of the Family of the Lechmeres of Fanhope in $y^{e}$ County of Hereford, whofe Effigies this is."

On a broken nab formerly in the principal aifle of the church, but now removed to the northern, or Lechmere chancel, beneath three fhields, with the arms of Lechmere and Overbury, and a blank fhield :-

$$
\begin{aligned}
& \text { "Edmund Lechmere Efq" : } \\
& \text { departed this life July } 3 \mathbf{I} \\
& 1650 \text {, xtatis anno } 74 \text {. } \\
& \text { MARGARET HIS WIFE, DAVGHTER } \\
& \text { of } \mathrm{S}^{\mathrm{r}} \text { Nicolas Overbvry } \mathrm{K}^{\mathrm{nt}} \\
& \text { DEPARTED THIS LIFE MARCH } \\
& 14^{\text {th }} 1634 \text {, xtatis. Anno } 42, \\
& \text { both lie here buried." }
\end{aligned}
$$

In the S.E. angle of the north chancel, on a blue flab, the arms of Lechmere impaling Sandys with the Lechmere creft, on a torfe a pelican, as in the arms :-

1 See page 14 .

2 The creft of Lechmere is a pelican azure sulning itfelf, on a torfe of the colours, or and gules. Since Lord Lechmere's time it is generally placed on a ducal coronet or. 


\section{Hanley and the}

Terra hæc fervat depofitum Nichi

Lechmere Militis ad confuñationem

Sæculi et tunc reddit.

Obiit 30 die Aprilis anno $\left\{\begin{array}{lc}\text { Dñi. } & 1701 . \\ \text { Ætat : } & 88 .\end{array}\right.$

mifericordias Domini in Æternum

Cantabo.

Uxorem duxit Penelopen, filiam

Edwini Sandys de Norborn in Cor̃ :

Cant: militis, ex qua numerofam

Reliquit progeniem fuperftitem."

On a blue flab adjoining the laft, the arms of Lechmere impaling Hungerford, with the creft as before :-

\section{" Hic dormit in Chrifto \\ Edms Lechmere Arm.}

Filius \& Hæres Nicholai Lechmere Mil:

Un' Baroñ Scc̃ii Dñi Regis Gul : tertii

apud Weft $\widetilde{m}$ :

In uxorem Duxit Luciam filiam

Antonit Hvngerford de Fareleigh

CAstle in Com̃ : Somerset Arח̃.

Ex qua fex filios \& quatuor filias

Habuit, \& reliquit Superftites.

Obiit $6^{\text {to }}$ die Iunii Anno Dor̃ 1703.

Etatis Suæ $55^{\circ}$

Fides in Patriam, Amicum \& Iuftum

Incorrupta, Conftans, \& Intrepida,

Imago viventis

Monumentum Mortui."

On an adjoining nlab, beneath the arms of Lechmere and Hungerford in a lozenge :- 


\section{House of Lechmere.}

"In Memory of

$M^{\text {rs }}$ Lucy Lechmere Widow.

Relict of Edmund Lechmere Esq ${ }^{r}$

\& daughter of Anthony Hungerford

of Farley Castle, Esq ${ }^{r}$ :

whofe Piety Virtue \& fingular Prudence

made Her a Bleffing to her Family

an Ornament to her Neighbourhood

an Example to her Equals

a Support to her Inferiors

a Delight to all

She died Nov : IX. Anno mpccxxix

Ætatis LXXX."

On an adjoining flab, beneath the arms of Lechmere, impaling Foley and the creft, in a ducal coronet :-

$$
\text { "H.S.E. }
$$

Antonius Lechmere arm̃ :

Quem repentinus apoplexiæ impetus e vivis rapuit,

Feb : 8. MDCcxx Atatis XLvi.

Perantiquæ qua oriundus erat familiæ Decus ita tuebatur, ut majorum fuorum virtutis hæres videretur nequaquam degener, Vir Ingenii fæcunditate et vivido animi vigore cum paucis fpectabilis, Erga inferiores comis adeo, urbanus, humilis ;

Inter pares adeo placidus, hilaris, decenter facetus, ut fummam apud illos venerationem, apud hos amorem facillimè retineret : omnibus ob fimplicem et inaffectatum geftum gratifimus.

Irenarchæ munus non prius fufcepit quam ornavit, Seditionis furorem cohibere, de tumultuantibus fupplicium fumere, nec minus falutem publicam promovere, quam pacem confervare. Inter litigantes vicinos benevolentiam reftituere, et inimicos amicifimos facere, Hic illi labor erat, hæc gloria. Inclytis fenatorum ordinibus aliquamdiu afcriptus, Sacra principis jura et inviolandas populi libertates, 


\section{Hanley and the}

conftanter fimul ac integerrime vindicando de patria optime meruit.

In matrimonio habuit Annam Thomæ Foley de Stoke Edith in agro Herefordienfi arm̃ : filiam.

Ex quo duo liberi, Edmundus, et Lucia, fufcepti, chariffimo patri fuperfunt."

On a flab adjoining that of Sir Nicholas Lechmere, the arms of Lechmere impaling Howard, with a Baron's coronet, the fupporters two leopards reguardant, ducally gorged, the creft on a ducal coronet:-

"Here lyeth the Body of the Right Honourable

Nicholas Lord Lechmere, Baron of Evefham.

Chancellour of the Duchy of LANCASTER and one of his Majesty's

Moft Honourable PRIVY Councell.

He was fecond Son to Edmund Lechmere Efq by

Lucy his wife Daughter of Antho. Hvngerford

Of Farley CASTLE, in the County of Somerfet Efq ${ }^{\mathrm{r}}$

He married Lady Eliz : Howard, Eldeft daughter to the

Right Honourable the EARL of CARLisLe

Dyed $18^{\text {th }}$ June 1727 . ann : ætat : 52 ."

On an adjoining flab, arms of Lechmere, creft on a tower :-

" Here lyeth the Body of William Lechmere $\mathrm{E} f \mathrm{q}^{\mathrm{r}}$ the fourth fon of EDMund Lechmere of Hanly Caftle in the County of Worcefter

Efq ${ }^{\mathrm{r}}$ by Lucy his Wife ; He departed this

Life, the twenty fixth day of September,

1725. Anno Etatis 47."

On a tablet at the eaft end of the north aifle is an infcription to the memory of Captain Edmund Lechmere, who died in 1703 , and is buried at St. Andrew's Church in Plymouth. This is not copied, as it is precifely the fame with the infcription already given at page 52 . 


\section{Houfe of Lechmere.}

On nabs at the north-eaftern corner of the north chancel :

" HERE LIE THE REMAINS OF WILLIAM LECHMERE ESQ ${ }^{r}$ OF STEEPLE ASTON IN THE COUNTY OF OXFORD, VICE ADMIRAL OF THE WHITE. WHO DIED I 2 Th day of DECEMBER, I 815 . AGED 63."

" UNDERNEATH ARE DEPOSITED THE REMAINS OF THE RIGHT HONOURABLE MARY BARONESS DE SAUMAREZ WIFE OF THE RIGHT HONOURABLE \& REV ${ }^{\text {d }}$ JAMES, SECOND LORD DE SAUMAREZ, AND DAUGHTER OF VICE ADMIRAL LECHMERE WHO DIED AFTER A FEW DAYS ILLNESS AT CHELTENHAM ON THE I $2^{\text {th }}$ DAY OF MAY, I 849 , aged 58."

"Watch therefore for ye know neither the day nor the hour wherein the Son of Man cometh. Matt. c. 25. v. 13."

"In Memory of Sir Antony Lechmere Bart.

Died March $25^{\text {th }} 1849$

Aged 82 years And of Mary his wife Died December $3^{\text {rd }}$ I 820

Aged $5 \mathrm{I}$ years Alfo of Mary Foley

Their daughter Died February 1803

Aged 3 years

And of Frances

Their daughter

Died January $29^{\text {th }} 1847$

Aged 56 years."

Engraved on brafs fixed to a black marble tablet at the eaftern end of the north chancel, under the arms of Lechmere :-

“ NEAR THIS SPOT REST THE MORTAL REMAINS OF Richard Lechmere Efq of Wick, Parifh of $S^{t}$ Johns Cy Worcefter (youngent 


\section{Hanley and the}

brother of Nicholas Lord Lechmere Baron of Evesham) born Jany $25^{\text {th }}$ I686, died Jany $28^{\text {th }}, 1774$. He was for fome years Secretary to the Britifh Embaffy at the Court of Ruffia. Alfo thofe of his wife Elizabeth, died March 21, 1781. She was the Relict of Tho ${ }^{8}$ Swift Efq ${ }^{r}$ of Slaughters Court, Powicke, $\mathrm{Cy}$ Worcefter, having by her firft marriage one fon. From her fecond marriage, there was iffue, viz: William Lechmere, Eff Vice Admiral of the White, Nicholas, who died on his eftate in the Inland of Jamaica, Lucy, who married Col: Thompkins of Wefton Turville Houfe Cy Buckingham, Elizabeth, who married Tho ${ }^{\mathrm{s}}$ Tudor Efq ${ }^{\mathrm{r}}$ of Garth Cy Montgomery and died leaving iffue.

HERE ALSO REST THE MORTAL REMAINS OF

William Lechmere Efq ${ }^{r}$ : (fon of the above named Richard Lechmere) who after long and meritorious fervice in the wars of his Country, rofe to the High Rank in his Profeffion of Vice Admiral of the White. He died Dec: $12^{\text {th }}, 1815$, at his Refidence, the Hill Houfe, Steeple Afton, Cy of Oxford. Vice-Admiral Lechmere married at $\mathrm{S}^{t}$ Martins in the Fields London, O\&t 31,1787, Elizabeth daughter of Sir John Dafhwood King Bart: of Weft Weycombe Houfe cy : Buckingham. Elizabeth his widow who furvived him for feven years \& died at Staverton Cy of Northampton and was buried at Halton Cy of Buckingham, one of the ancient feats of her Family. From this marriage there were ten children, of whom Lucy born Aug : 13, 1788, married Richard Parkinfon Efq of Kinnerfley Caftle Cy of Hereford, died and was buried at Hereford, leaving iffue a fon \& daughter, Charles born Dec: 4 I789 a Captain in the Royal Navy, whofe zeal \& enterprize (after he had feen much previous Service,) induced him to engage in a Survey of the Eaftern Coaft of Africa, where he died Nov: 9. I822, on board H.M.S. Leven, of a fever which carried off many of the officers \& crews of the two thips engaged in that fervice. MARY Baroness DE SAUMAREZ born, Ap : 2, 1791. Over a vault near this fpot is a flab infcribed to her memory. William born Jan ${ }^{y}$ 19, 1795, who died an Infant, \& was buried at Halton. Georgiana Sarah, born Jan ${ }^{y}$ 13. 1805, who died in 1820 , \& was buried at Vaumain near Gifor in France. Augusta born June 9. I 8 I o. who married James Montcrief Melville Efq ${ }^{r}$ of Hanley, Coftorphine, Cy of Edinburgh, the died in Childbirth, leaving iffue two fons and two daughters." 


\section{Houfe of Lechmere.}

\section{On a flab fixed to the exterior wall of the north chancel of Hanley Church :-}

"Here lyeth the body of Jane the wife of William Parfons Gentleman, and youngeft Daughter of Edmund Lechmere of Hanly Caftle $\mathrm{Efq}^{\mathrm{r}}$ Who

Departed this Life the $7^{\text {th }}$ day of January $A^{0} 1694$, aged 65.

"Here lyeth the Body of William

Parfons Gentleman, who departed

This Life, the $19^{\text {th }}$ day of January Ano 1694 . aged 65.

To fulfill the will of the Deceafed Jane Parfons, they were both laid in

This place of the church yard."

On a mural monument on the fouth fide of the nave :-

"To the Glory of God, and in affectionate memory of the Rev : Anthony Berwick Lechmere, M.A. Honorary Canon of Worcetter Cathedral and for 39 years Vicar of this parifh of Hanley Caftle, who departed this life Oet viii, A.D. MDccclxxviII. aged 76 years. Faithful to his Divine Mafter : devoted to his flock, beloved by all. His parifhioners and friends of all claffes erected this monument as a tribute to his worth and a lafting record of their deep regard."

On a coped tomb near the fouth door of the church, on the north fide :-

"In memory of Sir Edmund Hungerford Lechmere Baronet, who died April $2^{\text {nd }} 1856$. aged 63 years.

Bleffed are the pure in heart for they thall fee God. Matt v. 8.

In Thy Prefence, Lord, is fulnefs of joy. At thy right hand there are pleafures for ever more. Ps. xxi. ii.

The memory of the juft is bleffed." 


\section{Hanley and the}

On the fouth fide :-

" Here lies the body of The Hon ${ }^{\text {ble }}$ Maria Clara Widow of

Sir Edmund Hungerford Lechmere, Baronet.

who died Jan $29^{\text {th }} 1865$, aged 77 years.

Be thou faithful unto death and I will give thee a crown of life."

Rev : ii. 10.

On an adjoining tomb :-

"William Henry Lechmere Efquire, Born Oetober $15^{\text {th }} 1825$, died March 2 ${ }^{\text {nd }} 1857 . "$

"Sarah Lechmere, Born May $2^{\text {nd }} 1788$. died February $13^{\text {th }} 1862 . "$

On a large flat granite tomb, in the north-weftern part of Hanley churchyard :-

“Emily-Mary Lechmere. Born 3, March 1810. Died $18^{\text {th }}$ March 1869. Watch. Mark xiii. 37."

"Anthony Berwick Lechmere, for 39 years the devoted and beloved

Vicar of this Parifh. Who departed this life, Oct $8^{\text {th }} 1878 . "$

Faithful unto death."

"Eliza Anne Wall Born Aug : I ${ }^{\text {th }}$ 1789. Died Dec. 26 1875."

In Hanley-Caftle Church are feveral windows inforibed to the memory of members of the Lechmere family : the great weft window of the fouth or principal aifle bears the following infcription; it reprefents the Laft Judgment :-

" To the glory of God. and in memory of Sir Anthony Lechmere Baronet, and Mary his wife, this window was erected by their daughters Sarah and Eliza. Chriftmas mDccclx."

\section{On a fmall fouth-wett window :-}

" Erected by Thomas B. King in affectionate remembrance of Dame Eleanor Lechmere, Widow of Sir Anthony Lechmere, Bart : Rhyd Court, Upton on Severn. Buried at Wefton fuper Mare. Sep ${ }^{\text {tr }}$ 1. 1857 ." 


\section{Houje of Lechmere.}

On the eaft window of the fouth chancel, reprefenting the Crucifixion :-

" To the glory of God, and in memory of Sir Edmund Hungerford Lechmere Baronet, who died April 2n ${ }^{\text {nd }}$, 1856."

On the weft window of the north ainle :-

" To the glory of God this window is ereeted by the parihioners in affectionate remembrance of Emily-Mary, wife of the Rev. Anthony Berwick Lechmere, Vicar of this parifh. She died March I0. I869."

On the north window of the fame ainle :-

"In affectionate memory of Emily-Mary Lechmere this window is dedicated by the children of her two fifters."

FINIS.

CHISWICK PRESS:-C. WhITTINGHAM AND CO., TOOKS COURT, CHANCERY LANE. 




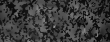

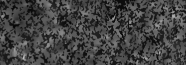

1. 1 .

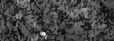

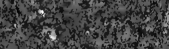

(2)

(x)

3.

T.t.

3x.

3
7

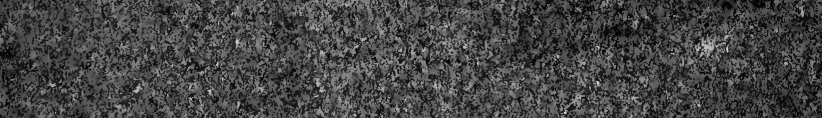

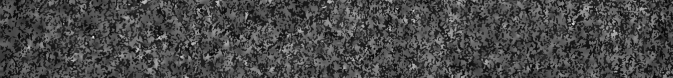

W.

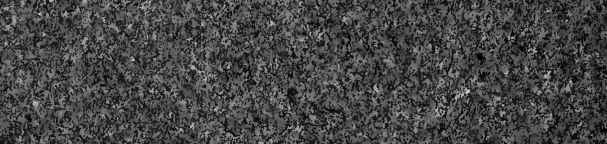

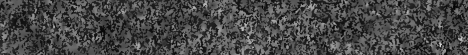

3
3

(1)

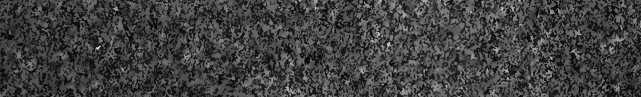
H.7.

1.

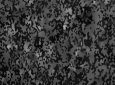

H.

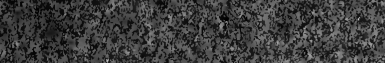

7.

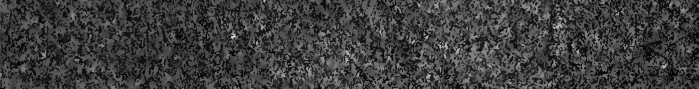

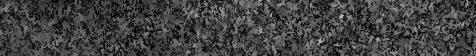

3.

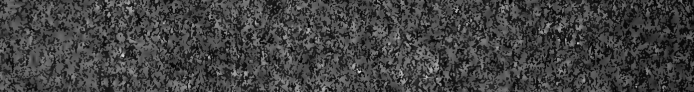

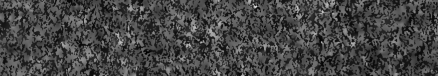

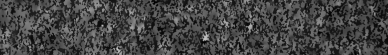

H. 